\title{
Uncertain model of industrial clusters for the optimal arrangement of co-operation networks under sustainable and dynamic conditions
}

\author{
Abbas Sarafrazi ${ }^{\mathrm{a}}$, Reza Tavakkoli-Moghaddam ${ }^{\mathrm{b}, *}$, Mahdi Bashiri ${ }^{\mathrm{c}, \mathrm{d}}$, and \\ Gholamreza Esmaeilian ${ }^{a}$
}

\begin{abstract}
a. Department of Industrial Engineering, Payame Noor University, PO BOX 19395-3697, Tehran, Iran.

b. School of Industrial Engineering, College of Engineering, University of Tehran, Tehran, Iran. c. School of Strategy \& Leadership, Faculty of Business and Law, Coventry University, Coventry, UK. d. Department of Industrial Engineering, Faculty of Engineering, Shahed University, Tehran, Iran.
\end{abstract}

\begin{abstract}
Industrial clusters are one of the most current development models. Aggregation of firms in a geographical area has many advantages, such as cost reduction, better supply, and knowledge emission with linkage together. The linkage result will be created the networks. The industrial clusters without co-operation networking will not be developed. That must be noticed to severe changes of business environment parameters. Therefore, this paper develops an uncertain mathematical model under sustainable and dynamic conditions. The model contains four objectives, namely profit, transportation cost, employment, and environment appraisal of the cluster. The outcome of this research is to find the best/optimal solution for firms' arrangements with/within networks that maximize the profit, employment, and environment score and so minimize the transportation cost. The assignment patterns show horizontal and vertical cooperation with/within networks. The efficiency of model clustering in sub-clusters is followed by the neighbor clustering efficiency and the one's clustering efficiency methods.
\end{abstract}

KEYWORDS: Industrial clusters; Multi-objective model; Co-operation network; Uncertainty; Sustainability.

\section{Introduction}

Industrial clusters in the recent four decades were one of the current and useful models of economic development. A study about clusters shows a vast range of quality and quantity researches. The economics of aggregate-base, like industrial cluster's models because of many benefits and advantages was developed all over the world from developing countries to developed countries. Nowadays, international organizations, United Nations Industrial Development Organization (UNIDO), International Labor Organization (ILO), and small and medium industries departments of countries are planning action plans to develop their industries that have been aggregated in a geographical region and industrial/ business same

\footnotetext{
* Corresponding author. Tel.: +982182084183.

E-mail addresses: a_sarafrazi@pnu.ac.ir(A.Sarafrazi); tavakoli@ut.ac.ir(R. Tavakkoli-Moghaddam); bashiri.m@gmail.com (M.Bashiri); gre@pnu.ac.ir(G.R. Esmaeilian).
} 
category and maybe have linkages with together. One of the comprehensive general industry development models is the industrial cluster. With the survey about the industrial and business patterns of the world can find that comprehensive pattern has been dominated by micro, small, and medium-sized enterprises (MSME). The World Bank has reported in 2010 that more than 123 countries with 125 million formal MSME have been registered that including 89 million emerged markets. Therefore, it is proven that clusters are wide, current, and general economic phenomena. Many developed and developing countries have been formed to 95 present MSME's firms averagely.

The industrial cluster is a suitable structure of industrial and economic for MSME's firms addressed in many industrial clusters' problems. Cluster theory and its application in clusterbased economic development have been a pioneer of economic development theories and methods during the three past decades. The cluster viewpoint proposes that enterprises are an area of a geographically defined cluster that benefits from being an area of that cluster and that these benefits result in development in the economic outcome for the district. A firm's proximity in an area creates more benefits because of decrease inputs costs and supply. Agglomeration and co-location of firms caused that flows knowledge and information within them. Common benefits of the firms increase willingness to participate for co-operation. The results of such actions increase productivity and competitiveness.

Therefore, the clusters are considerable and important for understanding and sustainable improving economic and industry growth. The policymakers and industry planners need to learn about effective actions and methods to take optimum decisions. According to this attention to cluster-based planning is a modern development method for governments. So understanding dynamic and functional industrial clusters is necessary for strategic planning.

In today's world, the decision-makers follow the variety of objectives of development that its concepts change continuously and cover more economic and social dimensions. Some objectives in regions economic include increasing and improvement of income and benefit, employment, export, technical men and knowledge spillover, skills, research and development, innovation, technology, various markets, vertical and horizontal corporation, relationships, trust-building, social responsively, welfare, environment considers and green products and decreasing and improvement costs, transports, energy consumption, poverty, waste and air/soil/water pollutions. Achievement of objectives and advantages of cluster development, analysis of clusters is an important step. The cluster analysis has been classified into quality and quantity methods. According to the literature review, all of the industrial clusters survey fields emphases to quality and conceptual analysis. Otherwise, the quantity analysis survey covered statistical methods and only a few surveys have been seen with mathematical and optimization models. So, this field of knowledge has a big research gap and this study has been tried to develop an optimization model with the mathematical approach. The industrial new concept's emphasis on the increase in the same firm's linkages and cocorporate empowerment, the linkages of firms together, and other stockholders in clusters creates phenomena that are named networks. The network building in clusters develops the process as a core activity that helps to cluster sustainability and many experts to believe that without networking, cluster development could not be completed. The general objective of networking gains more benefits for network members relative to when every member work 
alone. When firms work to gather within a network to determine a mission, the synergy will rise.

The main problem in network building is how to create an optimal/near-optimal/best network. What arrangement of firms can be optimal and suitable for assignments within networks? What is the optimal solution industrial cluster model under uncertain conditions?

This research tries to reply to questions by a mathematical model versus qualitative and experimental methods. The main benefits of networking in the model are to optimize the sustainable economic goals. This is a novel method for the network planners and decisionmakers about networking in industrial and business clusters. This solving method includes member firms within networks, amount of vertical and horizontal co-operation networks, a relationship of among firms with/within networks, co-operation planning of production, and joint actions as advantages of joint actions that will be more of the alone act that its named synergy. Nowadays, this subject is the core of the development plans literature of clusters and it is very widely used and practical. Moreover, the provided mathematical model in this study ensures to achieve an optimal network with sustainability concerns.

In rest of the paper has been organized as follows backgrounds include concepts and problem definition, literature review, and then problem mathematical modeling, solution method with case study, conclusion, and future studies.

\section{Background}

\subsection{Industrial cluster}

While Porter was the first person to come up with the idea of the industrial clusters in 1990; however, then different definitions of an industrial cluster were provided. Industrial clusters are generally defined as a group of producer and commercial firms and non-profit organizations in which competitive performance is the key element of a member of a group. What makes an integrated cluster is the interaction of member firms. Competitive enterprises would create competitive clusters and economic attractions will eventually close the clusters. Dimensions of space and time are the most important factors of the cluster policy which would influence the decision on the cluster programs. On the other hand, the original data and substances might impose limitations on the definition of the clusters. In the following, there will be various definitions of the cluster provided by scholars. First, a group of enterprises having strong vertical ties and located in a region that is close to each other geographically $[1,2]$. In the second and more comprehensive definition of Porter, a cluster is a geographic concentration of related enterprises and other firms in a special field [2].

In the broadcast sense, a cluster regards as the spatial concentration of economic activities. Opportunities related to the efficiency of mass are the factors drawing the attention of politicians to the clusters that originate from external economic costs and low transaction costs and collective action. Therefore, the spatial gathering of the enterprises that do not communicate with each other cannot increase the efficiency of mass. Therefore, a cluster is a set of relatively large economic firms located in a particular region and has a specific technical background in which firms do a thriving business. The local and geographical concentration of firms is called a cluster. This would lead to having external savings and recruiting of distant markets and also specialized services in the field of technical, financial 
and management will emerge. A cluster is a set of enterprises and organizations located in a geographical district that inner dependence causes an in-group relationship of products and services. Some of these enterprises like suppliers of resources and raw materials and applicants for goods and services linked together have complementary and similar products on a resource, process, or products [1,3]. A cluster is a group of enterprises focused on a geographical region facing common threats and opportunities providing related or complementary products [1]. This would lead to related businesses and emerging specialized services in the field of technical, management, and financial [1]. The industrial cluster is a set of homogenous industries developed with economic objectives in geographical regions for specific advantages and consistent social capital like technology and skills. The main characteristics of the industrial cluster are as follows [4]: (1) Concentration on a geographical region, (2) Business and the industrial interrelationship between member firms, (3) Vertical relationship in clusters, (4) Existence of non-commercial organizations along with commercial firms in a cluster, (5) Cooperate among firms and do common and popular activities, (6) Member competency, (7) Being in the same field of firms in one branch or specific industrial branch (value chain formation), (8) Common threats and opportunities for firms in a cluster, (9) Emerging specialized technical, mana gement and financial services in the cluster, (10) Dependence on an economic geographical specific region, (11) Synergy of competence and cooperation in the cluster, and (12) Mass efficiency of external economic savings.

A cluster is a set of enterprises, organizations, enterprises, and institutions, which are active in an industrial field that can synergy their capabilities [1]. The industrial cluster is generally formed on a local or urban geographical scale and has clear and various features [4]. Potentially, competitive industries tend to be a cluster in the economy ordered by data, skills, and infrastructures. The cluster concept has been used as an operational structure several times [4]. Recently, a mono-objective mathematical model is developed based on knowledge diffusion within the cluster [5].

Table 1 [4,6,7] and Table 2 [8] show different types of the cluster and a comparison of a network type in the cluster. The network activities types in MSME and industries are classified to management, the exchange of resources, and production of collective goods in an experimental study in Germany SME networks. They developed the concept of the organized network in co-operation and joint actions with 4000 networks for various industrials [9]. The last literature review about industrial clusters has found the network is one of the 10 top subjects in 25 top journals that publish to the cluster topic [10]. Therefore, the networks and relationships between industries, firms, clusters, and entities are a research gap and field of novel and applicable. The objective functions of the proposed model cover sustainable economic development aspects if the Dezfoulian's model has studied another aspect that is knowledge transfer among members. Also, the Sarafrazi's model [29] was studied about deterministic conditions by considering the sustainable economic development aspects.

\{Please insert Table 1 about here.

\{Please insert Table 2 about here. 
Based on Tables 1 to 3, the main pillar of the clusters is a relationship among the system component that is the networking. Relationship levels are different and create various networks. Table 2 categorizes the networks into three types (i.e., inter-firm, public, and regional). The first and fundamental level in the cluster atmosphere is the inter-firm networks created based on relationships and cooperation between firms and main players. Therefore, in the literature, the clusters and so final expected of the cluster development programs are networking and network reinforcement. The networks form from co-operation and joint actions. The main flow in the clusters is the process of organized goods/services. The firms within networks share their facilities and recourse to complete organized goods.

The vertical network is arranged based on production methods, engineering, and process sequence, like cutting, machinery, pressing, coloring, packing. The horizontal network is arranged bases on parallel operations and supporting activities like joint-buying, jointmarketing, joint-transportation, joint-testing. These activities complete the main output. The lateral network is arranged bases on machinery capacity exchange for higher demands.

By studying the literature from 1890 by Marshall [11] to now, the general aspect, all concepts, and definitions, the clusters are an agglomeration of similar units in a geographical region. Otherwise, the general goal of cluster development is to develop relationships and linkages that will lead to greater benefits. These more benefits are called synergy. In Table 3, these concepts and definitions are listed and developed by researchers in the last three decades. In all of these existing concepts, a general sense is an agglomeration and linkage. These two words (i.e., agglomeration and linkage) create the network. Therefore, the research is based on original concepts and goals that contribute to optimizing the model for cooperation optimal networks. The best arrangement of components and linkages between them are fundamental elements of the networks that it developed in this research.

\{Please insert Table 3 about here.

\subsection{Industrial cluster sustainability}

The main philosophy of the industrial clusters is regional economic development under sustainable conditions. Today industrial policymakers try to achieve new development objectives in addition to basic objectives. Firstly, fundamental objectives are increasing in benefit, income, economic, and enterprises' quantity growth. Secondly, other objectives are increasing in quality, employment; environment considers, and decreases in transportation and pollution types. So, there are three main considerations in the sustainable development concept includes economic, social, and environmental considerations as shown in Figure 1. Therefore, these objectives try to achieve wider and general development that includes a winwin-win concept for stockholder chains. First, win cover optimal benefit for market section include customer(s)/consumer(s), and second win cover optimal benefit for product section include producer(s)/supplier(s) and finally third win cover optimal benefit for social and environment section include protection of earth and human. Anyway, the researchers have developed many uncertainty multi-objective models for supply chain sustainable problems. The uncertainty includes fuzziness and randomness [30,31].

\{Please insert Figure 1 about here. 


\subsection{Cell manufacturing system}

The cellular phenomenon is a simplification action that helps in better understanding and operation in complex systems. Group technology (GT) is a philosophy related to production systems. The cell-oriented method of clustering parts and machines is similar in processing and operations in a family. Assign similar parts into a cell is named as the cellular manufacturing system (CMS). Parts group of similar are part families and are processed by machines set into cells. Cellular design improves the production process and so has many other advantages. One of the useful utilization of GT is the CMS which intention to organization large and varied categories or batches to small and medium categories of part types produced in the flow shop system [32-36]. The main advantages of cellular manufacturing have been published in the literature as simplification and reduction in material inner transportation, decreasing semi make and the work-in-process inventories, reduction in setup time, enhancement in flexibility, better production control, and shorter lead time [3739]. In today's competitive market and fluctuating environments, that must be developed systems by more efficient and economic models. One of the CMS branches is a virtual cellular manufacturing system (VCMS), which is based on "a highly flexible manufacturing concept designed to improve the performance of classical CMS and job shop manufacturing environments by creating a virtual grouping of the resources temporarily in the production planning and control system" [40,41]. In this case, machines cannot move physically within and between cells and change the cell's boundary logically. Rearrangements of facility and machines in a CMS cover additional costs include on machine movement cost; machines uninstall/install cost, setup cost; productions stop cost. However, in VCMS because of no machine movement, there are not these costs. Generally, a CMS is better for large companies with high technology; however, a VCMS improves this limitation for MSMEs companies with a lower cost.

\subsection{Problem definition}

The main approach to the industrial cluster's development is argued about the move from an unstable to a stable situation. Therefore, industrial planners and developers try to use improvement tools. In developing the process, cluster development agents and development organizations are intended to classify cluster members to efficiency and smaller sub-clusters that are co-located to subsets of main set firms in one region. This action is named networking in concepts of cluster development. The networks of the cluster were formed to satisfied stockholders' objectives and developed economic and social advantages. Generally, the network's pattern or membrane of firms in sub-clusters is done by quality methods that it not very exact and have to try and error. Therefore, the lack of quantitative analysis methods and mathematical optimization is an important research gap in this field. The research gap focuses on modeling under uncertain conditions in planning and cooperation networking. Therefore this research is an extension of fuzzy in the multi-objective programming proposed by the previous model. The research addresses to be optimal to solve of industrial cluster pattern with a variety of objectives. Because the problem has been extended, the model design has been considered several objectives and it is important that noticed to industrial, economic, social, and environmental considerations. There are lots of objectives to solve industrial 
problems. However, a multi-objective approach is more useful and valuable compared to other objectives and single-objective problems. So the industrial cluster problem model is designed with four objectives to include the maximization of a sub-cluster or cluster benefit, maximization of employment, minimization of material transport cost, and finally maximization of green appraisal respectively. This is a novel model and method for network planners and decision-makers about networking in industrial and business clusters under uncertainty and dynamic conditions. Nowadays this subject is the core of development planes literature of clusters and it is very widely used and practical. As illustrated in a comparison table for the literature review, it is shown that this study focuses on two aspects of horizontal and vertical collaboration in industrial clusters. To achieve the horizontal collaboration possibility, we suggest a clustering algorithm; however, a mathematical model is presented to construct the vertical collaboration network. The mentioned novelties have been added to the end of the "Literature review" section.

In this study, the industrial cluster model has been designed for a multi-objective optimization problem. Four main objectives cover development sustainability concepts. To meet and cover to sustainable development approach, four goals of economic, financial, social, and environment identified [31,42]. These goals are described more as follows;

1. Profit is an important economic goal that will grow clusters and firms and also will increase the motivation for development and cooperation.

2. The transportation cost is another important economic goal that needs to be decreased by optimal planning. This goal will cause an impact on the economic and environmental aspects by reducing fuel consumption and environmental pollution and also indirectly will have a positive social impact on the quality of life.

3. The employment goal is social and is considered in this study.

4. The environmental goal is important and necessary that protects the environment in terms of soil, water, air, and waste.

We consider the above-mentioned objectives to ensure that the designed industrial clusters network to be sustainable.

The first objective is the maximization of a firm's benefit [7] that increase business power and continuous motivation and is the main objective. This objective is related to economic consideration. The second objective is the maximization of employment in a region [7]. This objective is related to social and economic considerations. The third objective is the minimization of the cost of material handling and transportation $[7,11,43]$. This objective is related to economic consideration on the other hand decreasing carbon pollution and environmental consideration. The fourth objective is the maximization of green appraisal [44]. This objective is related to environmental considerations and green production principles.

The research procedure of industrial clusters for co-operation networks is as follows:

\section{Step I: First clustering}

1. Select of the industrial cluster with $f$ firms and enterprises and MSME structure.

2. Determine the most important of variables for clustering with a full covering of objectives for the cluster development context. 111 variables are in the current research.

3. Clustering of firms with Wards / $K$-means methods and divide them to $C$ sub-cluster to decreases the problem dimensions with maximum similarity of firms each other. 
4. Validate clustering results and sub-clusters.

Step II: Mathematical modeling with sustainable development objectives

5. Input one of the sub-clusters to a multi-objective model with uncertainty conditions in demand and firms capacity.

6. Input data.

7. Select LP-metric/Epsilon-constraint methods.

8. Solve the model with GAMS sofware.

9. Repeat the model solving and setting parameters and so determinate efficiency of assignments.

10. Construct a new network from two clusters by random selection of firms and then solving a new network based on the developed models.

11. Construct the networks and linkages with/within firms of the network(s) members.

\section{Mathematical model}

\subsection{Multi-objective optimization}

A mono-objective optimization algorithm is terminated upon obtaining an optimal solution, yet it is unlikely to find a single solution for a multi-objective problem and due to the contradictory objectives, we generally find a set of solutions. To clarify the point, some basic multi-objective concepts are reviewed below. The general multi-objective minimization problem is formulated by:

$$
\begin{gathered}
\text { Minimize }\{f 1(x), f 2(x) \ldots f m(x)\} \\
\text { s.t. } \\
g(x) \leq 0,
\end{gathered}
$$

where $x=(x 1, x 2 \ldots x n)$ is a vector of the decision variables, $F(x)=(f 1(x), f 2(x), \ldots, f m(x))$ is the vector of the solution in the objective space and $g(x)$ is the constraint vector. The CMS modeling has been developed with various assumptions and objectives [44-53]. The solution strategy for multi-objective problems is the epsilon-constraint method [54]. In the epsilonconstraint method is optimized one of the objective functions using the other objective functions as constraints, incorporating them in the constraint part of the model. In fuzzy building, details are referenced to Safaei's work [39].

\subsection{Problem mathematical modeling}

The mathematical model in this research was designed based on multi-objective modeling. The model was formulated as a nonlinear mixed-integer programming model. Due to the wide scope of the main problem, the model is formulated based on the following assumptions:

\section{Product:}

(1) Product times for all operations of a product on various firms (manufacture) are defined and deterministic.

(2) Each product has various operations/cooperation that must be accomplished as numbered, respectively. 


\section{Firm:}

(3) All firms are assumed to be micro, small, and medium enterprises.

(4) The benefit (value) of the cooperation class between firms is defined.

(5) The benefit (value) of each firm is defined.

(6) Capabilities of each firm are uncertain over the planning horizon capacity of each firm in each time horizon is given as piecewise an uncertain (fuzzy) number. The uncertain capacity of the firm is specified by the industrial cluster experts.

\section{Sub-cluster:}

(7) The maximum number of sub-clusters/clusters can be defined in each time horizon is determined in advance.

(8) The maximum sub-clusters/clusters size is defined in advance.

\section{Demand/ Inventory:}

(9) Demands are uncertain and constant over the planning horizon. The demand for each product in each time horizon is defined as a piecewise uncertain (fuzzy) number.

(10) Demand for each product in each time horizon is uncertain.

(11) The demand for a product in a given time horizon can be fulfilled before and after times.

(12) Backlogging and shortages are not permissive.

(13) The cost of transporting raw material/work-in-process (WIP) from the supplier to the firm is included in the raw material procuring cost.

(14) Cost of waste disposal is not contained in the problem.

(15) Supply is equal or more of demands for each product at sub-cluster/cluster and the shortage is not allowed because parameters are deterministic.

(16) Important weight/coefficient of each objective function is constant over the planning horizon.

(17) In the supply chain of the cluster, there is a variety of activities include the manufacturing and services base of value chains of products.

(18) Planning horizon in the industrial cluster will be considered medium and long term.

\section{Cooperation:}

(19) Cooperation between firms has positive effects that are synergy.

(20) When each firm has a guaranty benefit for cooperation so that it connects to subcluster/cluster.

(21) Cooperation between firms to sub-cluster/cluster will have had minimal benefit but according to synergy theory benefit is more of alone.

(22) Cooperation between firms to sub-cluster/cluster will have been having extended employment more of firm business lonely.

(23) Each firm can work in several operations with other firms/members to industrial clusters.

(24) Each firm can work in several cooperation fields with other firms/members to industrial clusters.

(25) The intervals for possible values of fuzzy parameters are defined by the expert as $\left[a^{L}, a^{U}\right]$ implicating a linear piecewise membership function. 
In general, linear piecewise membership functions can be divided into two main intervals. The first interval, $\left[0, a^{L}\right]$, represents "risk-free". $a^{L}$ is a predetermined aspiration level by the cluster planner. The second interval, $\left[0, a^{U}\right]$, represents "full-risk". While moving from "riskfree" toward "full-risk" values, it is moved from solutions with a high degree to solutions with a low degree of implementation [55]. In general, $a^{L}$ and $a^{U}$ indicate the optimistic and pessimistic orientation of the cluster planner, respectively.

\section{Notations, indices, and parameters}

$\lambda$ Lambda is named "decision level" that indicates the degree of membership of $X^{*}$ in the fuzzy variables set $D$.

$Z_{U}$ Objective function's maximum

$Z_{L} \quad$ Objective function's minimum

$c$ Index for manufacturing firm's sub-clusters/clusters, $c=(1, \ldots, C)$

$c^{\prime}$ Index for manufacturing firms at another sub-clusters/clusters, $c^{\prime}=\left(1, \ldots, C^{\prime}\right)$

$f \quad$ Index for firm (enterprise, manufacture) types, $f=(1, \ldots, F)$

$f^{\prime}$ Index for firm (manufacture) types at another sub-clusters/clusters, $f=(1, \ldots, F)$

$p \quad$ Index for product types, $p=(1, \ldots, p)$

$h$ Index for time horizons, $h=(1, \ldots, h)$

$j \quad$ Index for operations that belongs to product $p, j=(1, \ldots, J)$

$k$ Index for other cooperation that belongs to product $p, k=(1, \ldots, K)$

$P \quad$ Number of product types

$F \quad$ Number of firm types

$H$ Number of time horizons

$J \quad$ Number of cooperation between firms (operations/process) for product $p$

$K$ Number of other cooperation between firms (operations/process) for product $p$

$C$ Maximum number of sub-clusters/clusters that can be designed

$D_{j p h} \quad$ Demand for product $p$ in cooperation (operations/process) $j$ between firms at the period $\mathrm{h}$

$\tilde{D_{j p h}}=\left(D_{j p h}^{L}, D_{j p h}^{U}\right)$ Fuzzy demand expresses a tolerance value and decision making under this interval risky or "full-risk" value-interval for the cluster expert

$D_{j p h}^{L} \quad$ Fuzzy demand of operation $j$ for product pin time horizon $h$ were equivalent to the linguistic expression "about $D_{j p h}^{L}$ or less and low demand"

$D_{j p h}^{U} \quad$ Fuzzy demand of operation $\mathrm{j}$ for product pin time horizon $h$ were equivalent to the linguistic expression "about $D_{j p h}^{U}$ or more and up demand"

$Q_{p h} \quad$ Demand quantity of product $p$ at time horizon $h$

$D_{p h}^{\sim}=\left(D_{p h}^{L}, D_{p h}^{U}\right)$ Fuzzy demand expresses a tolerance value and decision making under this interval risky or "full-risk" value-interval for the cluster expert

$D_{p h}^{L} \quad$ Fuzzy demand of product pin time horizon $h$ were equivalent to the linguistic expression "about $D_{p h}^{L}$ or less and low demand"

$D_{p h}^{U} \quad$ Fuzzy demand of product pin time horizon $h$ were equivalent to the linguistic expression "about $D_{p h}^{U}$ or more and low demand"

$U B \quad$ Maximal cluster size 
$b_{j p f} \quad$ Benefit (value) for product $p$ in cooperation (operations/process) $j$ by firm $f$

$w_{j p} \quad$ Cluster policy important weight for product $p$ in cooperation (operations/process) $j$

$w_{k p} \quad$ Cluster policy important weight for product $p$ in cooperation (operations/process) $k$

$\beta_{j k p} \quad$ Portion of benefit (additional benefit/award) for product $p$ in cooperation fields (operations/process) $j$ and $k$ between firms

$a_{j p f} 1$ if cooperation (operations/process) $j$ of product $p$ can be done at firm $f ; 0$, otherwise

$a_{k p f} 1$ if other cooperation (operations/process) $k$ of product $p$ can be done at firm $f ; 0$, otherwise

$T_{f} \quad$ Capacity of firm $f$ in each time horizon

$T_{f}^{\tilde{f}}=\left(T_{f}^{L}, T_{f}^{U}\right) \quad$ Fuzzy capacity expresses a tolerance value and decision making under this interval risky or "full-risk" value-interval for the cluster expert

$T_{f}^{L} \quad$ Fuzzy capacity of firm $\mathrm{f}$ in each time horizon were equivalent to the linguistic expression "about $T_{f}^{L}$ or less and low capacity"

$T_{f}^{U} \quad$ Fuzzy demand of operation $j$ for product pin time horizon $h$ were identical to the linguistic expression "about $T_{f}^{U}$ or more and up to capacity"

$U B_{f} \quad$ Maximal expected benefit of the firm

$L B_{j p} \quad$ Minimal (lower bound) operation/cooperation $j$ for product $p$

$U B_{j p} \quad$ Maximal (upper bound) operation/cooperation $j$ for product $p$

$f c \quad$ Maximal (upper bound) profit of operation/cooperation $j$ for product $p$ in firm $f$ to subcluster's/ cluster's $c$ at time horizon $h$

ic Maximal (upper bound) profit of operation/cooperation $k$ for product $p$ in firm $f$ to sub- cluster's/ cluster's $c$ at the time horizon $h$

$E_{j p f c h}$ Employment number for product $p$ in cooperation (operations/process) $j$ in firm $f$ allocated cluster's/ cluster's $c$ at the time horizon $h$

$E G_{j p f c h}$ Employment number for product $p$ in cooperation (operations/process) $j$ in firm $f$ allocated cluster's/ cluster's $c$ at the time horizon $h$ for the green objective

$E_{k p f c h}$ Employment number for product $p$ in cooperation (operations/process) $k$ in firm $f$ allocated to cluster's/ cluster's $c$ at time horizon $h$

$\alpha_{j p}$ Minimal of expected percentage for employment on operation/cooperation $j$ for product $p$ $W_{p}$ Weight of product $p$

$L W_{\text {jp }}$ Weight of employment product $p$ in cooperation (operations/process) $j$

$L W G_{j p}$ Weight of employment product $p$ in cooperation (operations/process) $j$ for green

$S_{j p f c h}$ Green appraisal scores of operation $j$ for firm $f$ for product $p$ allocated to sub-cluster's/ cluster's $c$ at time horizon $h$ [56].

$G_{j p f c h}^{q}$ Green appraisals score of operation $j$ for firm $f$ for product $p$ allocated to sub-cluster's/ cluster's $c$ at time horizon $h$ for every item of $q$

$W^{q}$ Importance weight of $q$ items green appraisals

\section{Decision variables}

$X_{j p f c h} 1$ if product $p$ in cooperation (operations/process) $j$ in firm $f$ allocated cluster's/ cluster's $c$ at the time horizon $h$ is assigned; 0, otherwise 
$X_{\text {kpfch }} 1$ if product $p$ in cooperation (operations/process) $k$ in firm $f$ allocated to cluster's/ cluster's $c$ at the time horizon $h$ is assigned; 0, otherwise

$N_{f c h}$ Number firm $f$ allocated to cluster's/ cluster's $c$ at the time horizon $h$

By using mentioned notations, the proposed model under mixed-integer nonlinear programming (MINLP) that is a multi-objective industrial cluster optimization is written as follows (Eqs. (2) to (25)):

Z1: Maximization of the objective function of the benefit (value chain)

$\operatorname{Max} \lambda$

$$
\begin{aligned}
(\mathrm{ZU}-\mathrm{ZL}) \leq \mathrm{ZU} & -\sum_{h=1}^{H} \sum_{f=1}^{F} \sum_{c=1}^{C} N_{f c h} b_{f c h} \\
& +\sum_{h=1}^{H} \sum_{f=1}^{F} \sum_{c=1}^{C} \sum_{p=1}^{P} \sum_{j=1}^{J} X_{j p f c h} b_{j p f} \cdot\left[(1-\lambda) \cdot D_{j p h}^{L}+\lambda \cdot D_{j p h}^{U}\right] w_{j p} \\
& +\sum_{h=1}^{H} \sum_{f=1}^{F} \sum_{c=1}^{C} \sum_{p=1}^{P} \sum_{j=1}^{J} \sum_{k=1}^{K} \beta_{j k p} \cdot X_{j p f c h} \cdot X_{k p f c h}+\sum_{h=1}^{H} \sum_{f=1}^{F} \sum_{c=1}^{C} \sum_{p=1}^{P} \sum_{j=1}^{J} \gamma_{j p f} S_{j p f c h} \cdot X_{j p f c h}
\end{aligned}
$$

Z2: Maximization of the objective function of the employment

$$
\sum_{h=1}^{H} \sum_{f=1}^{F} \sum_{c=1}^{C} \sum_{p=1}^{P} \sum_{j=1}^{J} X_{j p f c h} . E_{j p f c h} . L W_{j p}+\sum_{h=1}^{H} \sum_{f=1}^{F} \sum_{c=1}^{C} \sum_{p=1}^{P} \sum_{j=1}^{J} X_{j p f c h} . E G_{j p f c h} . L W G_{j p}
$$

Z3: Minimization of the objective function of the material handling cost

$$
\begin{aligned}
(\mathrm{ZU}-\mathrm{ZL}) \leq \mathrm{Z} & -\sum_{p=1}^{P} \sum_{h=1}^{H} \frac{\left[(1-\lambda) \cdot D_{p h}^{L}+\lambda \cdot D_{p h}^{U}\right]}{B} \times \gamma_{p h}^{\text {inter }} \\
& \times\left[\sum_{j=1}^{J} \sum_{p=1}^{P} J_{j p} \cdot d_{f(f+1)}-\left(\sum_{j=1}^{J} \sum_{p=1}^{P} \sum_{f=1}^{F} \sum_{c=1}^{C} \sum_{h=1}^{H} d_{f(f+1)} \cdot X_{j p f c h} \cdot X_{j+1, p, f+1, c, h}\right)\right] \\
& +\sum_{p=1}^{P} \sum_{h=1}^{H} \frac{\left[(1-\lambda) \cdot D_{p h}^{L}+\lambda \cdot D_{p h}^{U}\right]}{B} \times \gamma_{p h}^{\text {intra }} \\
& \times\left(\sum_{j=1}^{J} \sum_{p=1}^{P} \sum_{f=1}^{F} \sum_{c=1}^{C} \sum_{h=1}^{H} d_{f(f+1)} \cdot X_{j p f c h} \cdot X_{j+1, p, f+1, c, h}\right)
\end{aligned}
$$

Z4: Maximization of the objective function of the green appraisals

$$
\begin{aligned}
& \sum_{h=1 f}^{H} \sum_{f=1}^{F} \sum_{c=1}^{C} \sum_{p=1}^{P} X_{j p f c h} . S_{j p f c h} \\
& S_{j p f c h}=\sum_{q=1}^{Q=24} W^{q} \cdot G_{j p f c h}^{q}
\end{aligned}
$$

s.t.

Benefit (value) of industrial cluster constraints:

Constraints (7) and (8) are related to assignment one to one for every operation and joint activates. 
$\sum_{j=1}^{J} \sum_{f=1}^{F} \sum_{c=1}^{C} \sum_{p=1}^{P} a_{j p f} . X_{j p f c h}=1, \forall h$

$\sum_{k=1}^{K} \sum_{f=1}^{F} \sum_{c=1}^{C} \sum_{p=1}^{P} a_{k p f} . X_{k p f c h}=1, \forall h$

Constraint (9) explains weights accumulate of product and operation is equal products no.

$\sum_{j=1}^{J} \sum_{p=1}^{P} w_{j p}=\sum_{p=1}^{P} p$

Constraint (10) explains, weights accumulating the product operation for every product are 1.

$\sum_{j=1}^{J} w_{j p}=1 \quad, \forall p$

Constraint (11) explains firm the capacity for every sub-cluster and planning horizon.

$\sum_{j=1}^{J} \sum_{f=1}^{F} \sum_{p=1}^{P}\left[(1-\lambda) \cdot D_{p h}^{L}+\lambda \cdot D_{p h}^{U}\right] \cdot X_{j p f c h} \cdot t_{j p f} \leq\left[(1-\lambda) T_{f}^{L}+\lambda T_{f}^{U} \quad, \forall c, h\right.$

Constraint (12) explains the Max size of sub-cluster for every sub-cluster and planning horizon.

$\sum_{f=1}^{F} N_{f c h} \leq U B_{c}, \forall c, h$

Constraints (13) and (14) explain the Min size of sub-cluster for every sub-cluster and planning horizon.

$\sum_{c=1}^{C} \sum_{f=1}^{F} N_{f c h} \geq 1, \forall h$

$\left(N_{f c h}-N_{f c(h-1)}\right) \geq 0$

Constraints (15) explain the profit (value) of co-operation for every sub-cluster and planning horizon.

$N_{f c h} \times b_{f c h} \geq \sum_{h=1}^{H} \sum_{f=1}^{F} b_{f h}$

Constraints (16) and (17) related to upper and lower bound of firm capacity and operations of products for every planning horizon.

$\sum_{c=1}^{C} \sum_{f=1}^{F} \sum_{p=1}^{P} b_{j p f} \cdot\left[(1-\lambda) \cdot D_{p h}^{L}+\lambda \cdot D_{p h}^{U}\right] \cdot X_{j p f c h} \geq U B_{f}, \forall h$

$L B_{j p} \leq \sum_{c=1}^{C} \sum_{f=1}^{F} \sum_{p=1}^{P} \sum_{j=1}^{J}\left[(1-\lambda) \cdot D_{j p h}^{L}+\lambda \cdot D_{j p h}^{U}\right] \cdot X_{j p f c h} \leq U B_{j p}, \forall h$

Constraints (18) to (20) related to upper and lower bounds of operations, joint action and product for every firm and sub-cluster and planning horizon.

$L B_{j} \leq \sum_{j=1}^{J} X_{j p f c h} \leq U B_{j}, \forall p, f, c, h$
$L B_{k} \leq \sum_{k=1}^{K} X_{k p f c h} \leq U B_{k}, \forall p, f, c, h$ 
$L B_{p} \leq \sum_{p=1}^{P} X_{j p f c h} \leq U B_{p}, \forall j, f, c, h$

Employment of industrial cluster constraints:

Constraints (21) and (22) explain that network/ sub-cluster employment is more of employment of horizon planning and positive.

$$
\begin{aligned}
& \sum_{c=1}^{C} \sum_{f=1}^{F} \sum_{p=1}^{P} \sum_{j=1}^{J} \sum_{h=1}^{H} E_{j p f c h} \cdot X_{j p f c h}+\sum_{c=1}^{C} \sum_{f=1}^{F} \sum_{p=1}^{P} \sum_{j=1}^{J} \sum_{h=1}^{H} E G_{j p f c h} \cdot X_{j p f c h} \\
& \leq \alpha_{j p} \times\left(\sum_{j=1}^{J} \sum_{f=1}^{F} \sum_{c=1}^{C} \sum_{p=1}^{P} E_{j p f c}+\sum_{j=1}^{J} \sum_{f=1}^{F} \sum_{c=1}^{C} \sum_{p=1}^{P} E G_{j p f c}\right), \quad \forall h \\
& \left(E_{j p f c h}+E G_{j p f c h}\right)-\left(E_{j p f c(h-1)}+E G_{j p f c(h-1)}\right) \geq 0
\end{aligned}
$$

Binary constraints:

$$
X_{j p f c h}, X_{k p f c h} \in\{0,1\}
$$

Non-negative constraints:

$$
\begin{aligned}
& N_{f c h}, D_{j p h}, \beta_{j k p} \geq 0 \\
& S_{j p f c h,} E_{j p f c h,} \geq 0
\end{aligned}
$$

\subsection{Linearization of the industrial cluster multi-objective model}

Two objective functions are nonlinear because of the quadratic terms in the first and third objective functions. Two binary decision-maker variables multiplied in these objectives. The nonlinear sentences can be linearized simply by defining auxiliary binary variables to replace them. Such changes require some additional constraints to be added to the model. The variables can be expressed by change of the variable:

Wrijj_k $k_{-}=X s r i j k X s+1, r i j \_k_{-} \forall i, j, j, r, s, k, k$

Through a change of the variable on a binary variable, the corresponding additional constraints are as follows:

$X s r i j k+X s+1, r i j \_k_{-} \leq 1+W s r i j j \_k k_{-} \forall i, j, j, r, s, k, k$,

$X s r i j k+X s+1, r i j \_k_{-} \geq 2 W s r i j j \_k k_{-} \forall i, j, j \_r, s, k, k$,

\section{Experimental results}

To examine the model has been defined as a case study of a stone industrial cluster that it is included 5 similar firms with 2 main products, 3 product operations, 3 corporation operations within firms, 2 sub-clusters (networks), and 2 horizons. In the first step of the research, the firms are clustered according to their similarities. This will lead to a decrease in the size of the 
problem and so by experiments. By using this step the number of firms was reduced to 5 clusters (representative firms) among 100 firms using 111 variables. In the second stage of the research, the network is constructed by using a mathematical introduced model in 2019. It is distinguished that the problem is non-convex/nonlinear and four objectives that cannot be optimally solved within a suitable and rational time. By increasing problem dimensions, solving time is very high. Therefore, the model is a hard problem and very complex that was solved very hard. This research was used Minitab and GAMS software. The model was solved by GAMS codding under Win7. Table 4 presents data of uncertain production capacity and so demand of industrial cluster firms in two horizons. The production capacity of firms is constant in each period because of the change of capacity need for investment and strategic decisions; however, market demands and orders are dynamic that cover triangular fuzzy linguistics' data.

\{Please insert Table 4 about here.

The results of optimal or near-optimal solutions present in Table 4 under deterministic and uncertain conditions. The one number in Table 5 shows which firm $f$ allocate to sub-cluster $c$ that assignment to process operation $\mathrm{j}$ of product $p$ on time horizon $h$. These draw to subcluster arrangement maps in the cluster context. Each objective function in the multi-objective has an important weight that is used in LP-metric and epsilon constraint methods [57]. For determination of $w_{i}$ is applied two methods include expert's judgment and experiments. Experimental results showed that $w_{i}$ in the experimental method create the best solutions. Finally, a parameter setting for $W 1=0.1, W 2=0.05, W 3=0.8$, and $W 4=0.05$ gives the best results for model objectives.

The assignment patterns show horizontal and vertical cooperation with/within firms. When some firms do the same activity is named horizontal cooperation in the sub-cluster that supply market demand aided capacity together, like firms 1 and 2 in sub-cluster 1 work together in operation $j 1$ for product 2 on horizon 1 and so firm 2, 4, and 5 in sub-cluster 1 work together in operation $j 2$ for product 2 on horizon1. On the other when some firms do different activities that complete together and has operation sequence is named vertical cooperation in the sub-cluster that product a final product/service like firms 2, 4, and 3 in sub-cluster1 have operation sequence $j 1, j 2$, and $j 3$ for product 1 on horizon 1 , respectively. To determine the model clustering efficiency in sub-clusters is followed by the neighbor clustering efficiency (NCE) and the ones clustering efficiency (OCE) methods. Tables 6 and 7 show clustering efficiency results.

Table 5 shows a relationship pattern of a firm's activities. The activities include production operations $j$ and supporting operations $k$ that one number present to assignment status. So, cooperation production plan in time horizons for various products in vertical and horizontal networks prepare for planners. For example, vertical co-operation network for product-1(P1) in time horizon-1(H1) have located in subcluster-1(C1) and the vertical network has arranged to firm-2, firm-4 and firm-3 for operation route 1-2-3, respectively (F2---J1, F4---J2, F3---J3). The horizontal co-operation network for product-1(P1) in time horizon-1(H1) has located in subcluster-1(C1) and the horizontal network has been arranged to firm-1 to firm5 for separate joint actions 1-2-3. The first network is F1, F2, F3, F4, and F5 for joint action-1(K1) that is 
material common buying, and so on. The preferred solution among the Pareto optimal solutions is extracted according to the planner's preferences. In the numerical example, it was assumed by experimental tests that the preferred weights of four objectives are $0.1,0.05,0.8$, and 0.05 , respectively. However, it can be changed in different situations or industrial sectors.

Tables 6 and 7 show the efficiency of clustering in networks that focus on firms amount that assign to a network that more percentages present to higher quality in assignment. Amount equal and more than 80 percent usually is a suitable decision.

\{Please insert Table 5 about here.

\{Please insert Table 6 about here.

\{Please insert Table 7 about here.\}

\section{Conclusion and discussion}

This paper was presented a novel mixed-integer nonlinear programming (MINLP) model for a developed and extended industrial cluster model under dynamic and uncertain conditions with the fuzzy demand and fuzzy firm capacity [29]. The global business current atmosphere follows rapid changes therefore more suitable and real models can be dynamic and uncertain. A dynamic environment mentions the changing product demand in each time horizon proposed model determines the optimal sub-cluster arrangement for each period with the four objectives of maximizing profit, employment, and green appraisal, minimizing inter/intra subcluster material handling of firms. The principal advantage of the proposed model is to consider dynamic and uncertain conditions at the same time and so is to cover important dimensions of the cluster business environment with sustainable conditions. Other benefits of the model are alternative product plans, sequence operation, firm's suitable arrangement, and share firm resources. The main constraints of the proposed model are the maximal cluster size and fuzzy firm capacity. A new fuzzy programming approach was used for handling such a hard model under an uncertain environment. This approach was based on the concept of maximizing the decision proposed by Bellman and Zadeh [58].

The research applied a fuzzy method while the technological coefficients were repeated in the objective function(s). The gained results presented that the developed fuzzy method could give the optimal solution with the most desirable of fuzzy objective(s) and constraints under dynamic and uncertain conditions. The results of the model showed more improvement in solutions in Table 8 . The profit objective $\mathrm{Z} 1$ gained 16 presents, the employment objective $\mathrm{Z} 2$ gained more than 2.59 present, the material handling cost objective Z3 was not changed, and the final green appraisal objective Z4 gained 4.57 present. Generally, the solution was improved and the decision-maker objectives were satisfied more. The efficiency of firms' assignment in industrial cluster networks under uncertainty for corporation operation $k$ was 93 percent and operation $j$ was 78 and 90 percent that total average was 88 percent. The efficiency amount for this model was suitable and acceptable.

\{Please insert Table 8 about here.\} 
The sensitivity analysis is used in the business world of the clusters and the field of economics and industries. Sensitivity analyses study how various sources of uncertainty in a mathematical model contribute to the model's overall uncertainty. In this research, the sensitivity analysis of the fuzzy model determines the suitable demand lower bound (DLB) and demand upper bound (DUB). The range of the demand coefficient is shown in Table 9. The results show that the profit objective (Z1) is improved by 34.55 percent and 6.26 percent for total function. The transportation objective $(Z 2)$ is decreased by 17.36 percent and others objectives are not changed. The suitable range of the demand coefficient is found in the DLB [0.5-0.6] and the DUB [1.45-1.55].

\{Please insert Table 9 about here.\}

After solving the model for each co-operation network, this paper proposes a new approach in the network design. In this part of the research, there are two separate cooperation networks in the industrial cluster. Networks have five and eight firms inside each sub-cluster. In this approach, a new network with five firms is created randomly between the members of the two networks. The solution of the new co-operation network is compared to the previous networks in Table 10.

\section{\{Please insert Table 10 about here.}

Results show that a new network with five firms by using the fuzzy and LP-metric methods has a better solution. The objective function values $Z 1, Z 3$, and $Z 4$ have better solutions; however, the objective function value $Z 4$ is better in the old network with a deterministic status. Figures 2 to 5 shows the position of the objective functions in different states of their analyses.

\{Please insert Figure 2 about here.

\{Please insert Figure 3 about here.\}

\{Please insert Figure 4 about here.

\{Please insert Figure 5 about here.\}

On the other hand, one of the most important practical findings of this study is the appropriate and efficient number of members in the co-operation network as shown in Table 11. In the literature on networking in the development of industrial clusters in India, Tunisia, and more than $31 \%$ in Italy by UNIDO [59] qualitative studies have shown that the average number of network members in the clusters is between 8 to 12 members, while this study proves that the range of the appropriate and an optimal number of firms within the network is between 5 to 8 members.

\{Please insert Table 11 about here.\}

The practical advice for industry and regional economy is based on a research point to scientific networking in clusters from qualitative methods to optimal and exact methods used 
in a suitable pattern of networks, relationships and flows between them. This study offers the solutions of arrangements and their linkages with/within networks for players of the cluster. The most action of planners in the development programs of clusters is networking. The vertical and horizontal networks of cooperation are the core of action plans for development agents and their organizations. These networks in vertical status (e.g., joint production, complementary processes, consortium, and sub-contracting) and in horizontal status (e.g., common lab, design center, and joint purchasing of material) as well as so other types of networking (e.g., subcontracting and partnership exchange (SPX) networking model and consortiums).

This fuzzy method conducts nonlinear crisp programming that cannot be solved within a reasonable time even for small-sized problems. Thus, the meta-heuristic algorithms that can help to solve the models in large sizes are proposed for future researches. So the industrial cluster system has a wide variety of objectives for suitable economic development that can be developed and tested. So in more future studies in the main decision variable, other scenarios can be developed in dimensions and indices. In a co-operation network, if the firms have various or parallel production lines with different technologies, it can be considered in the developed model. Moreover considering the labour assignment can be considered during the network design as well as the clustering stage as another direction for future study.

\section{References}

[1] Caron, H. J. and Pouder, R. W. "Technology Clusters versus Industry Clusters: Resources, Networks, and Regional Advantages", Growth and Change, 37(2): pp. 141-171 (2006).

[2] Majidi, J. "Cluster or industrial clusters", Small Industries \& Industrial Parks Organization, Tehran (2003).

[3] He, J. and Fallah, M.H. "The typology of technology clusters and its evolution: Evidence from the hi-tech industries", Technological Forecasting \& Social Change, 78(6), pp. 945-952 (2011).

[4] Del-Angizan, S. "Science and technology clusters toward a common theory", Journal of Parks and Growth and Technology Centers, 5(2), pp. 16-29 (2011).

[5] Dezfoulian, H.R., Afrazeh, A. and Karimi, B. "A new model to optimize the knowledge exchange in industrial cluster: A case study of Semnan plaster production industrial cluster", Sciatica Iranica - Transaction E journal, 24(2), pp. 834-846 (2017).

[6] Gordon, I.R. and McCann, P. "Industrial clusters: Complexes, agglomeration and/or social networks?", Urban Studies, 37(3), pp. 513-532 (2000).

[7] Porter, M.E. "Clusters and the new economics of competition", Harvard Business Review, 76(6), pp. 77-90 (1998).

[8] Sprenger, R.U. "Inter-firm networks and regional networks opportunities for employment and environmental protection", Institute for Economic Research (IFO), Munich, (2001).

[9] Glückler, J. and Hammer, I. "Cooperation gains and network goods", Business Networks Reloaded book, Publisher in Nomos Ashgate, pp. 22-41 (2015).

[10] Lu, R., Reve, T., Huang, J. and et al. "A literature review of cluster theory: Are relations among clusters important?”, Journal of Economic Surveys, 32 (4), pp. 1201-1220 (2018).

[11] Marshall, A. "Principles of economics", 8th Edition, MacMillan, London (1920).

[12] Krugman, P. "Increasing returns and economic geography", Journal of Political Economy, 99(3), pp. 483-499 (1991).

[13] Saxenian, A. "Regional advantage: Culture and competition in Silicon Valley and route 128", MA: Harvard University Press, Cambridge (1994). 
[14] Simmie, J. and Sennett, J. "Innovation in the London metropolitan region", in: D. Hart, J. Simmie, P. Wood, and J. Sennett (Eds.), Innovative clusters and competitive cities in the UK and Europe", Working Paper, No. 182, Oxford (1999).

[15] Roelandt, T.J. and Den Hertog, P. "Cluster analysis and cluster policy in the Netherlands", Boosting Innovation: the cluster approach, 31, pp. 9-23 (1999).

[16] Hill, E. and Brennan, J. "A methodology for identifying the drivers of industrial clusters: The foundation of regional competitive advantage", Economic Development Quarterly, 14(1), pp. 6596 (2000).

[17] Van den Berg, L., Braun, E. and Van Winden, W. "Growth clusters in European cities: An integral approach", Urban Studies, 38(1), pp. 185-205 (2001).

[18] Ketels, C. "The development of the cluster concept-present experiences and further developments", in: NRW Conference on Clusters, Duisberg, Germany, vol. 5 (2003).

[19] OECD, "Organization for economic co-operation and development the DAC guidelines", Strategies for Sustainable Development, Paris (2001).

[20] Rosenfeld, S.T. "Industry clusters: Business choice, policy outcome, or branding strategy?", Journal of New Business Ideas and Trends, 3(2), pp. 4-13 (2005).

[21] Cortright, J. "Making sense of clusters: Regional competitiveness and economic development", Impresa, Inc., The Brookings Institution, 4, pp. 56-62 (2006).

[22] Schilling, M. "Technological innovation management strategies Book", Mohammad Aerabi and Mohammad Taghi Zade Motlagh, Cultural Research Office, Second edition (2011).

[23] Glaeser, E. and Gottlieb, J. "The wealth of cities: agglomeration economies and spatial equilibrium in the United States", Journal of Economic Literature, 47(4), pp. 983-1028 (2009).

[24] Wolman, H. and Hincapie, D. "Clusters and cluster-based development: A literature review and policy discussion, Working Paper, George Washington Institute of Public Policy, The George Washington University, pp. 1-45 (2010).

[25] UNIDO "Industrial development report learning and innovation through competing", Vienna (2003).

[26] Sheffi, Y. "Logistics clusters: delivering value and driving growth", MIT press (2012).

[27] Delgado, M., Porter, M.E. and Stern, S. "Defining clusters of related industries", Journal of Economic Geography, 16 (1), pp. 1-38 (2016).

[28] Lu, R., Reve, T., Huang, J. and et al. "A literature review of cluster theory: Are relations among clusters important?”, Journal of Economic Surveys, 32 (4), pp. 1201-1220 (2018).

[29] Sarafrazi, A., Bashiri, M. and Tavakkoli-Moghaddam, R. "Multi-objective modeling of industrial clusters from the perspective of dynamic cellular manufacturing systems and sustainable economic development", Econometric Modeling Journal, 3(2), pp. 49-91, (2019).

[30] Yu, H., and Solvang, W.D. "A fuzzy-stochastic multi-objective model for sustainable planning of a closed-loop supply chain considering mixed uncertainty and network flexibility", Journal of Cleaner Production, 266, Art. No. 121702 (2020).

[31] Mohammadia, A.S., Alemtabriza, A., Pishvaeeb , M, and et al. "A multi-stage stochastic programming model for sustainable closed-loop supply chain network design with financial decisions: A case study of plastic production and recycling supply chain", Scientia IranicaTransactions E journal, 27(1), pp. 377-395 (2020).

[32] Babu, A.S. "Development of virtual cellular manufacturing systems for SME", Logistic Information Management, 13(4), pp. 228-243 (2000).

[33] Han, W., Zhao, J.L. and Chen, Y. "A virtual cellular manufacturing system design model based on axiomatic design theory", Applied mechanics and Materials, 271, pp. 1478-1484 (2012). 
[34] Han, W., Liu, J. and Mei, L. "The resource conflict resolution problem for virtual cellular manufacturing inter-cell scheduling under the conditions of resource sharing", Applied Mechanics and Materials, 527, pp. 286-293 (2014).

[35] Khilwani, N., Ulutas, B.H., Islier A.A. and et al. "A methodology to design virtual cellular manufacturing systems”, Journal of Intelligent Manufacturing, 22, pp. 533-544 (2011).

[36] Rezazadeh, H., Mahini, R. and Zarei, M. "Solving a dynamic virtual cell formation problem by linear programming embedded particle swarm optimization algorithm", Applied Soft Computing, 11, pp. 3160-3169 (2011).

[37] Renna, P. "Design policies in virtual cellular manufacturing systems by multi-domain simulation environment", Applied Mechanics and Materials, 718, pp. 192-197 (2015).

[38] Askin, R.G. and Strada, S. "A survey of cellular manufacturing practices", in: S. Irani (Ed.), Handbook of Cellular Manufacturing Systems, John Wiley, New York (1999).

[39] Safaei, N., Saidi-Mehrabad, M. and Babakhani, M. "Designing cellular manufacturing systems under dynamic and uncertain conditions", Journal of Intelligent Manufacturing, 18(3), pp. 383399 (2007).

[40] Hamedi, M., Esmaeilian, G. and Napsiahbt, I. "Developing capability-based virtual cellular manufacturing systems and comparison with capability-based classical cellular manufacturing systems", Applied Mechanics and Materials, 110, pp. 3938-3946 (2012).

[41] Nomden, G. and van der Zee, D.J. "Virtual cellular manufacturing configuring routing flexibility", International Journal of Production Economics, 112, pp. 439-451 (2008).

[42] Silva, J.D., Fernandes, V., Limont, M. and Rauen, W.B. "Sustainable development assessment from a capitals perspective: Analytical structure and indicator selection criteria", Journal of Environmental Management, 260, Article No. 110147 (2020).

[43] Feser, E.J. and Bergman, E.M. "National industry cluster templates: A framework for applied regional cluster analysis", Regional Studies, 34(1), 1-19 (2000).

[44] Pouya, A. and Ghorbanpor, A. "The clustering of industries in fuzzy environment by green supply chain for environment management", Urban Management Journal, 39 (9), pp. 71-86 (2014).

[45] Sarayloo, F. and Tavakkoli-Moghaddam, R. "Multi-objective particle Swarm optimization for a dynamic cell formation problem, in: D.S. Huang et al. (Eds.), Proceedings of the 6th Int. Conf. on Intelligent Computing (ICIC), Changsha, China, 18-22 August 2010, CCIS 93, pp., Springer, Heidelberg (2010).

[46] Dimopoulos, C. "Multi-objective optimization of manufacturing cell design", International Journal of Production Research, 44(22), pp. 4855-4875 (2006).

[47] Zitzler, E. and Thiele, L. "Multi-objective evolutionary algorithms: A comparative case study and the strength Pareto approach", IEEE Transactions on Evolutionary Computation, 3(4), pp. 257271 (1999).

[48] Bajestani, M.A., Rabbani, M., Rahimi-Vahed and et al. "A multi-objective scatter search for a dynamic cell formation problem", Computers \& Operations Research, 36(3), pp. 777-794 (2009).

[49] Shirazi, H., Kia, R., Javadian, N. and Tavakkoli-Moghaddam, R. "An archived multi-objective simulated annealing for a dynamic cellular manufacturing system", Journal of Industrial Engineering - International, 10(2), 1-17 (2014).

[50] Safaei, N. and Tavakkoli-Moghaddam, R. "Integrated multi-period cell formation and subcontracting production planning in dynamic cellular manufacturing systems, International Journal of Production Economics, 120(2), pp. 301-314 (2009). 
[51] Kia, R., Shirazi, H., Javadian, N. and Tavakkoli-Moghaddam, R. "A multi-objective model for designing a group layout of a dynamic cellular manufacturing system”, Journal of Industrial Engineering - International, 9(8), pp. 1-14 (2013).

[52] Mahdavi, I., Paydar, M. and Solimanpur, M. "Multi-objective cell formation and production planning in dynamic virtual cellular manufacturing systems", International Journal of Production Research, 49(21), pp. 6517-6537 (2011).

[53] Ariafar, S., Ismail, N., Tang, S.H. and et al. "Design of a facility layout model in hybrid cellular manufacturing systems under variable demand", International Journal of Industrial and Systems Engineering, 9(4), pp. 373-387 (2011).

[54] Mavrotas, G. "Effective implementation of the e-constraint method in multi-objective mathematical programming problems", Applied Mathematics and Computation, 213(2), pp. 455465 (2009).

[55] Arikan, F. and Gungor, Z. "A parametric model for cell formation and exceptional elements' problems with fuzzy parameters", Journal of Intelligent Manufacturing, 16(1), pp. 103-114 (2005).

[56] Yeh, W.C. and Chuang, M.C. "Using multi-objective genetic algorithm for partner selection in green supply chain”, Expert Systems with Applications, 38, pp. $4244-4253$ (2011).

[57] Noorossana, R. and Kamali-Ardakani, M. "A weighted metric method to optimize multi-response robust problems", Journal of Industrial Engineering - International, 8(5), pp. 10-19 (2009).

[58] Bellman, R.E. and Zadeh, L.A. "Decision Making in a Fuzzy Environment". Management Sciences, 17, pp. 141-164 (1970).

[59] UNIDO "Development of clusters and networks of SMEs: The UNIDO program, A guide to export consortia", Vienna, 35 (2005).

\section{List of figure captions}

Figure 1. Diagram of sustainability development considerations [19].

Figure 2. Improvement trend of the profit objective function.

Figure 3. Improvement trend of the employment objective function.

Figure 4. Improvement trend of the transportation cost objective function.

Figure 5. Improvement trend of the green appraisal objective function

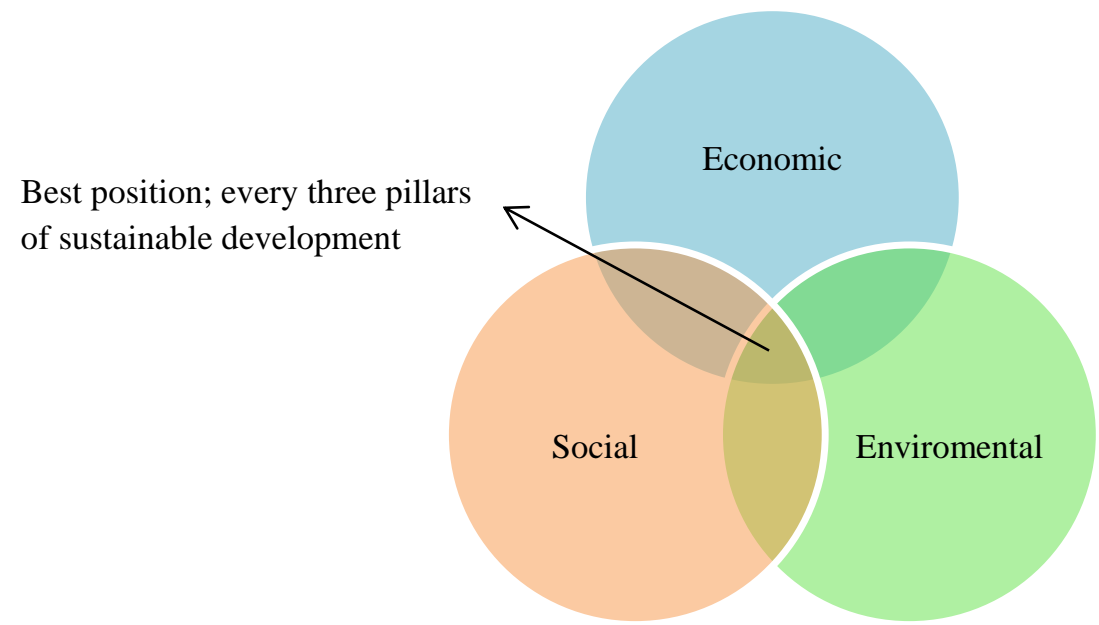

Figure 1. Diagram of sustainability development considerations [19]. 


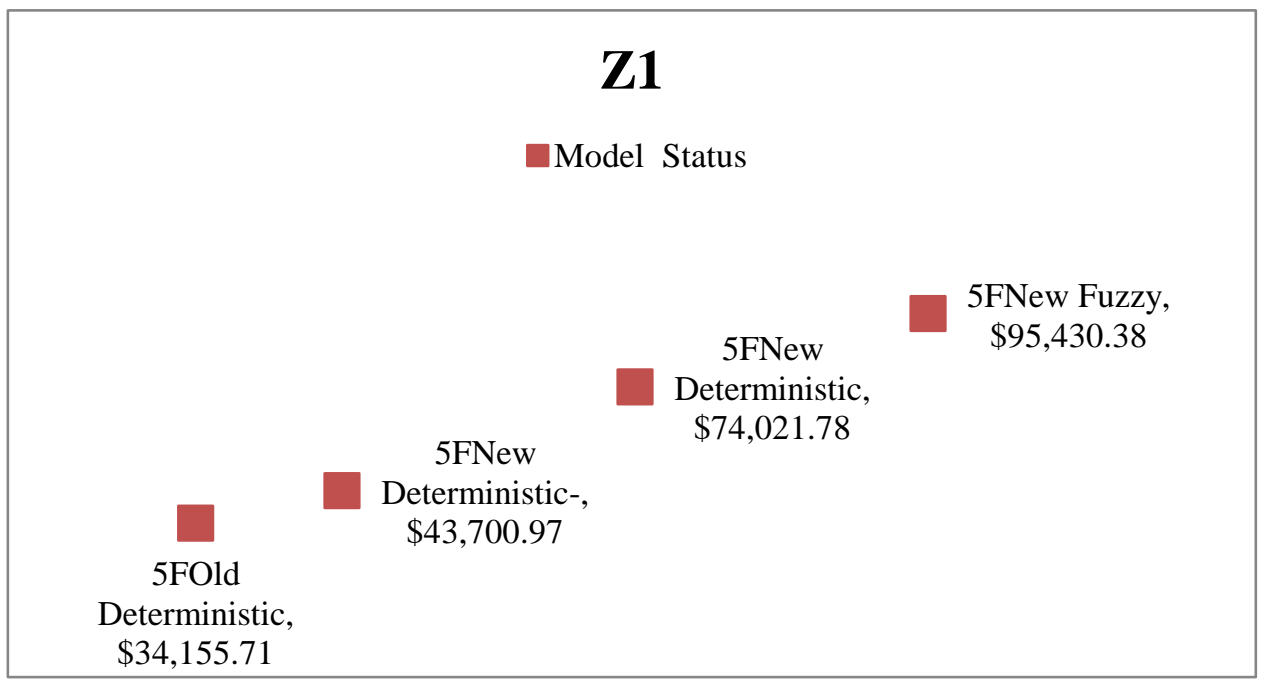

Figure 2. Improvement trend of the profit objective function.

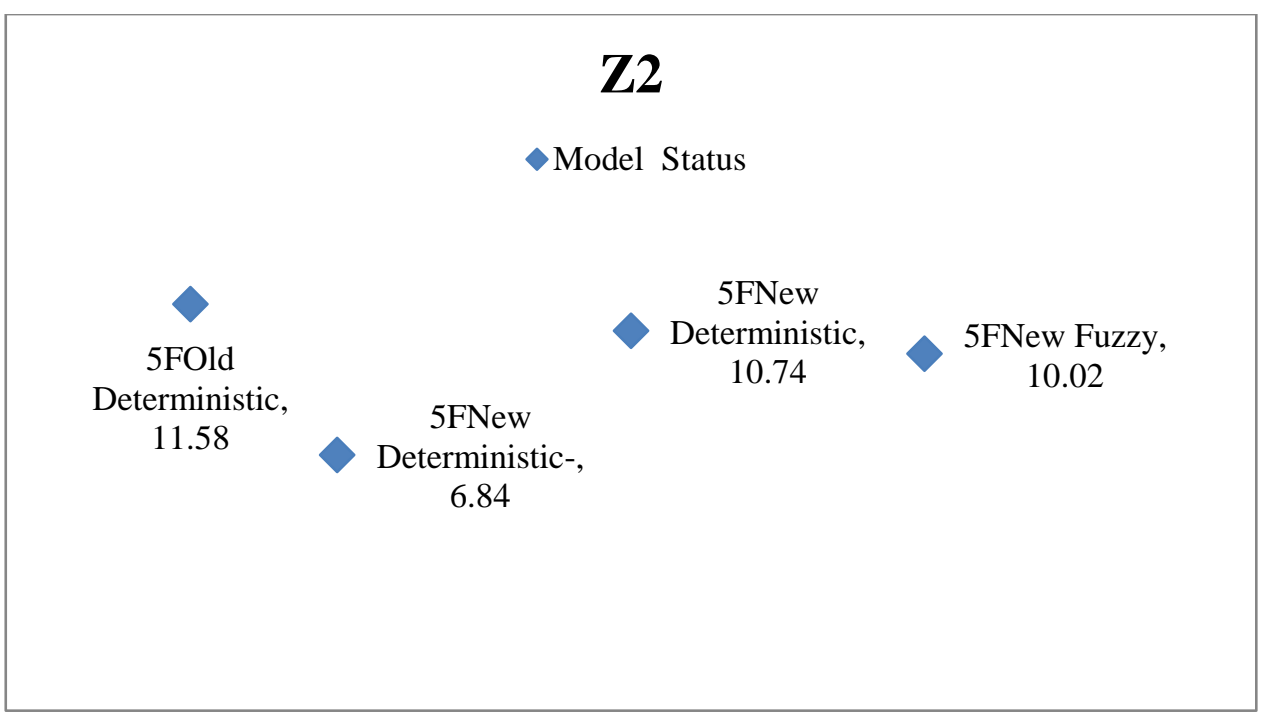

Figure 3. Trend of the employment objective function.

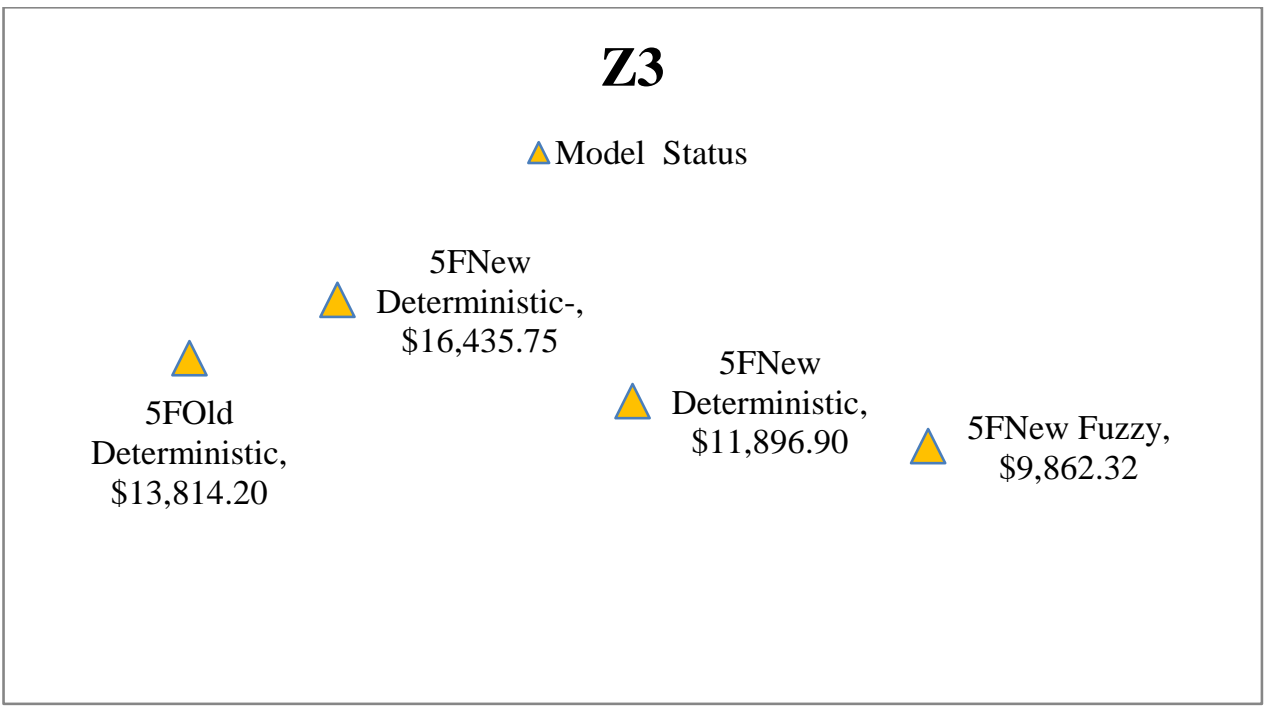

Figure 4. Improvement trend of the transportation cost objective function. 


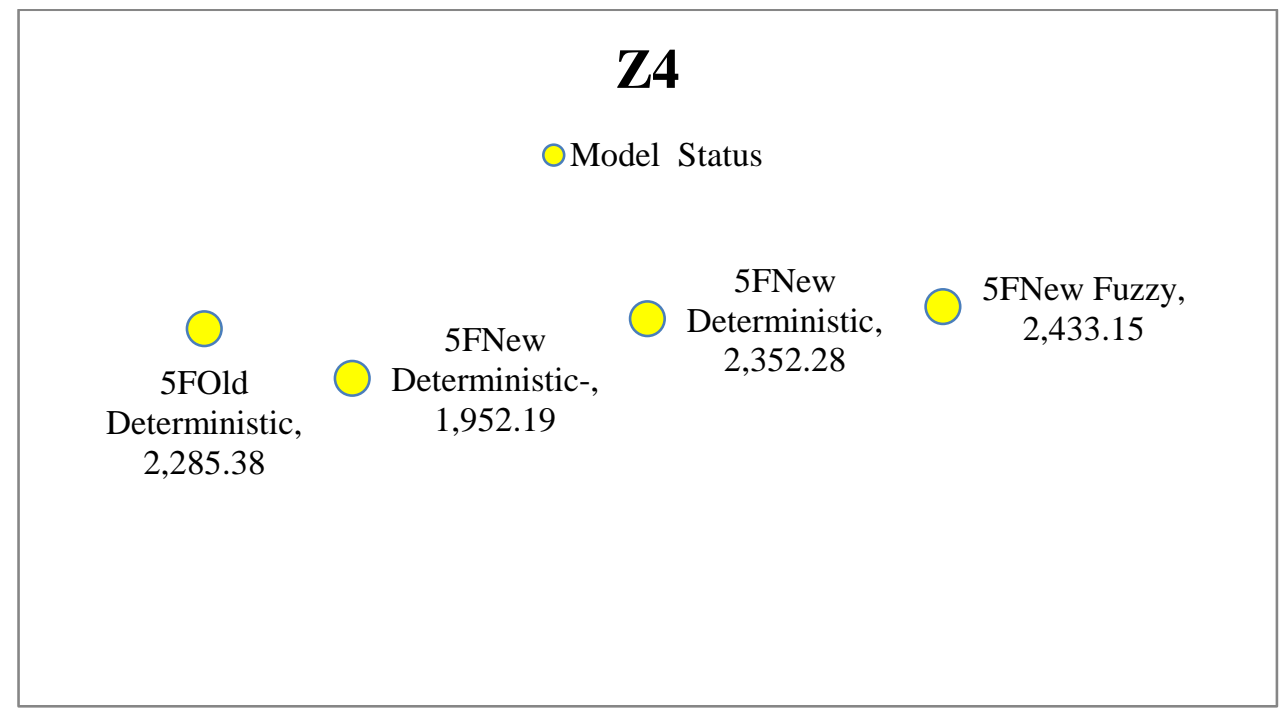

Figure 5. Improvement trend of the green appraisal objective function

\section{List of table captions}

Table 1. Types of clusters.

Table 2. Comparison of the network type in the cluster.

Table 3. Literature review of cluster models and concepts.

Table 4. Uncertain production capacity and demand of industrial cluster firms.

Table 5. Optimal solutions from the uncertain model for the industrial cluster.

Table 6. Efficiency measures for clustering of firms in the industrial cluster under uncertainty.

Table 7. Efficiency of firms in industrial cluster networks under uncertainty.

Table 8. Comparative of deterministic and uncertain models with optimal solutions of clusters.

Table 9. Model sensitivity analysis with optimal solutions of clusters.

Table 10. A new approach of the cluster model in the old and new proposed combinations of the network.

Table 11. Comparison of changes and growth of model objectives with the number of optimal members of the research and experimental co-operation networks.

Table 1. Types of clusters.

\begin{tabular}{|l|l|l|l|l|}
\hline \multicolumn{7}{|c|}{ Cluster type } \\
\hline \multicolumn{1}{|c|}{ Cluster/index } & \multicolumn{1}{|c|}{ Enterprises size } & \multicolumn{1}{c|}{ product } & \multicolumn{1}{c|}{ Knowledge } & \multicolumn{1}{|c|}{ skill } \\
\hline Business cluster & micro/small & product/service & low/medium & low/medium \\
\hline Industrial cluster & small/medium/large & product & medium/high & medium/high \\
\hline Technology cluster & small/medium/large & product/service & high/very high & high \\
\hline Green cluster & small/medium/large & product & medium/high & medium \\
\hline Pure agglomeration & micro/small/medium/large & product/service & low/medium & low/medium \\
\hline Industrial complex & medium/large & product & medium/high & medium \\
\hline networks & micro/small/medium & product/service & low/medium/high & low/medium \\
\hline
\end{tabular}

Source: Researcher findings 
Table 2. Comparison of the network type in the cluster.

\begin{tabular}{|c|c|c|c|}
\hline $\begin{array}{c}\text { Network/ } \\
\text { Characteristics }\end{array}$ & $\begin{array}{l}\text { Inter-firm } \\
\text { networks }\end{array}$ & $\begin{array}{c}\text { Public and other institutional } \\
\text { networks }\end{array}$ & $\begin{array}{l}\text { Regional } \\
\text { networks }\end{array}$ \\
\hline Players & $\begin{array}{l}\text { Businesses, especially } \\
\text { MSMEs }\end{array}$ & $\begin{array}{l}\text { Municipalities, } \\
\text { educational and research } \\
\text { institutes }\end{array}$ & $\begin{array}{l}\text { Businesses, governmental } \\
\text { offices, intermediary } \\
\text { institutions, social groups }\end{array}$ \\
\hline Motives/Aims & $\begin{array}{l}\text { Improving } \\
\text { competitiveness }\end{array}$ & $\begin{array}{l}\text { Increased efficiency } \\
\text { through the division of } \\
\text { responsibilities }\end{array}$ & $\begin{array}{l}\text { Sustainable solutions, } \\
\text { regional solutions }\end{array}$ \\
\hline $\begin{array}{l}\text { Areas of } \\
\text { cooperation } \\
\text { (examples) }\end{array}$ & $\begin{array}{l}\text { Supply, innovation, } \\
\text { disposal, waste, sales, } \\
\text { gain, ordering, law, } \\
\text { finance }\end{array}$ & $\begin{array}{l}\text { Transport, tourism, culture \& } \\
\text { education, utilities, and waste } \\
\text { disposal, business development } \\
\text { and management, } \\
\text { administration }\end{array}$ & $\begin{array}{l}\text { Regional planning, } \\
\text { marketing, linkages, } \\
\text { knowledge transfer, }\end{array}$ \\
\hline $\begin{array}{l}\text { Course of } \\
\text { cooperation }\end{array}$ & $\begin{array}{l}\text { Horizontal / vertical / } \\
\text { Lateral }\end{array}$ & Horizontal & $\begin{array}{l}\text { Cross-section / } \\
\text { Lateral }\end{array}$ \\
\hline $\begin{array}{l}\text { Adjustment system } \\
\text { and control }\end{array}$ & $\begin{array}{l}\text { Trust, basic } \\
\text { agreements, contracts }\end{array}$ & Agreements, contracts & Trust, agreements \\
\hline
\end{tabular}

Source: Sprenger [8].

Table 3. Literature review of cluster models and concepts.

\begin{tabular}{|c|c|c|c|c|c|}
\hline Researcher & Year & Cluster definitions/ Concepts & Objectives & Model & $\begin{array}{c}\text { Horizon/ } \\
\text { Status }\end{array}$ \\
\hline Marshall [11] & 1890 & $\begin{array}{l}\text { "Clusters as external economies created by } \\
\text { labor market pooling and the benefits of } \\
\text { moving people across firms, supplier } \\
\text { specialization, knowledge spillovers" }\end{array}$ & $\begin{array}{l}\text { Economic } \\
\text { knowledge }\end{array}$ & Conceptual & $\begin{array}{l}\text { Static/ } \\
\text { Certainty }\end{array}$ \\
\hline Krugman [12] & 1991 & $\begin{array}{l}\text { "New economic geography: Clusters as co- } \\
\text { location decisions of firms due to increasing } \\
\text { returns to scale, lower costs of moving } \\
\text { goods across space, etc." }\end{array}$ & Economic & Qualitative & $\begin{array}{l}\text { Static/ } \\
\text { Certainty }\end{array}$ \\
\hline Saxenian [13] & 1994 & $\begin{array}{l}\text { "Clusters as social and institutional } \\
\text { phenomena: technological change, } \\
\text { organizations, social networks, and other } \\
\text { non-market relationships in which markets } \\
\text { are embedded: organization within and } \\
\text { between businesses, the relationship } \\
\text { between firms" }\end{array}$ & $\begin{array}{l}\text { Economic } \\
\text { Social }\end{array}$ & $\begin{array}{l}\text { Qualitative/ } \\
\text { Conceptual }\end{array}$ & $\begin{array}{l}\text { Static/ } \\
\text { Certainty/ } \\
\text { Network }\end{array}$ \\
\hline Porter [7] & 1998 & $\begin{array}{l}\text { "Geographic concentrations of } \\
\text { interconnected companies and institutions in } \\
\text { a particular field, linked by commonalities } \\
\text { and complementarities. Clusters include } \\
\text { linked industries and other entities } \\
\text { (suppliers), distribution channels and } \\
\text { customers (demand), related institutions } \\
\text { (research organization, universities, training } \\
\text { entities, etc." }\end{array}$ & $\begin{array}{l}\text { Economic } \\
\text { Social }\end{array}$ & Conceptual & $\begin{array}{l}\text { Static/ } \\
\text { Certainty/ } \\
\text { Network }\end{array}$ \\
\hline $\begin{array}{l}\text { Simmie and } \\
\text { Sennett [14] }\end{array}$ & 1999 & $\begin{array}{l}\text { "An innovative cluster as a large number of } \\
\text { interconnected industrial and/ or service } \\
\text { companies having a high degree of } \\
\text { collaboration, typically through a supply } \\
\text { chain, and operating under the same market }\end{array}$ & $\begin{array}{l}\text { Economic } \\
\text { Social }\end{array}$ & Conceptual & $\begin{array}{l}\text { Static/ } \\
\text { Certainty/ } \\
\text { Network }\end{array}$ \\
\hline
\end{tabular}




\begin{tabular}{|c|c|c|c|c|c|}
\hline & & conditions" & & & \\
\hline $\begin{array}{l}\text { Roelandt and } \\
\text { Hertog [15] }\end{array}$ & 1999 & $\begin{array}{l}\text { "Industrial clusters can be characterized as } \\
\text { networks of producers of strongly } \\
\text { interdependent firms (including specialized } \\
\text { suppliers) linked each other in a value- } \\
\text { adding production chain" }\end{array}$ & $\begin{array}{l}\text { Economic } \\
\text { Social }\end{array}$ & $\begin{array}{l}\text { Qualitative/ } \\
\text { Conceptual }\end{array}$ & $\begin{array}{l}\text { Static/ } \\
\text { Certainty/ } \\
\text { Network }\end{array}$ \\
\hline $\begin{array}{l}\text { Hill and Brennan } \\
{[16]}\end{array}$ & 2000 & $\begin{array}{l}\text { "Industrial cluster as a geographic } \\
\text { concentration of competitive firms or } \\
\text { establishments in the same industry that } \\
\text { either has close buy-sell relationships with } \\
\text { other industries in the region or shares a } \\
\text { specialized labor pool that provides firms } \\
\text { with a competitive advantage over the same } \\
\text { industry in other places" }\end{array}$ & $\begin{array}{l}\text { Economic } \\
\text { Social }\end{array}$ & $\begin{array}{l}\text { Qualitative/ } \\
\text { Conceptual }\end{array}$ & $\begin{array}{l}\text { Static/ } \\
\text { Certainty }\end{array}$ \\
\hline $\begin{array}{l}\text { van den Berg, } \\
\text { Braun and van, } \\
\text { Winden [17] }\end{array}$ & 2001 & $\begin{array}{l}\text { "The popular term cluster is most closely } \\
\text { related to the local or regional dimension of } \\
\text { networks. Most definitions share the notion } \\
\text { of clusters as localized networks of } \\
\text { specialized organizations, whose production } \\
\text { processes are closely linked through the } \\
\text { exchange of goods, services and/ or } \\
\text { knowledge" }\end{array}$ & $\begin{array}{l}\text { Economic } \\
\text { Social } \\
\text { Knowledge }\end{array}$ & $\begin{array}{l}\text { Qualitative/ } \\
\text { Conceptual }\end{array}$ & $\begin{array}{l}\text { Static/ } \\
\text { Certainty/ } \\
\text { Network }\end{array}$ \\
\hline Ketels [18] & 2003 & $\begin{array}{l}\text { "Clusters are groups of companies and } \\
\text { institutions co-located in a specific } \\
\text { geographic region and linked by } \\
\text { interdependencies in providing a related } \\
\text { group of products and/or services" }\end{array}$ & $\begin{array}{l}\text { Economic } \\
\text { Social } \\
\text { Knowledge }\end{array}$ & Conceptual & $\begin{array}{l}\text { Static/ } \\
\text { Certainty/ } \\
\text { Network }\end{array}$ \\
\hline OECD [19] & 2005 & $\begin{array}{l}\text { "Clusters, local concentrations of } \\
\text { horizontally or vertically linked firms that } \\
\text { specialize in related lines of business } \\
\text { together with supporting organizations }\end{array}$ & $\begin{array}{l}\text { Economic } \\
\text { Social }\end{array}$ & Conceptual & $\begin{array}{l}\text { Static/ } \\
\text { Certainty/ } \\
\text { Network }\end{array}$ \\
\hline Rosenfeld [20] & 2005 & $\begin{array}{l}\text { "Clusters are simply geographic } \\
\text { concentrations of interrelated companies } \\
\text { and institutions of sufficient scale to } \\
\text { generate externalities" }\end{array}$ & $\begin{array}{l}\text { Economic } \\
\text { Social }\end{array}$ & $\begin{array}{l}\text { Qualitative/ } \\
\text { Conceptual }\end{array}$ & $\begin{array}{l}\text { Static/ } \\
\text { Certainty/ } \\
\text { Network }\end{array}$ \\
\hline Cortright [21] & 2006 & $\begin{array}{l}\text { "An industry cluster is a group of firms and } \\
\text { related economic actors and institutions, } \\
\text { that are located near one, another and that } \\
\text { draw productive advantage from their } \\
\text { mutual proximity and connections" }\end{array}$ & $\begin{array}{l}\text { Economic } \\
\text { Social }\end{array}$ & $\begin{array}{l}\text { Qualitative/ } \\
\text { Conceptual }\end{array}$ & $\begin{array}{l}\text { Static/ } \\
\text { Certainty/ } \\
\text { Network }\end{array}$ \\
\hline Schilling [22] & 2008 & $\begin{array}{l}\text { Technology Sets (clusters) are a collection } \\
\text { of companies that are located in a region } \\
\text { and liked to the same technology, and the } \\
\text { possible relationship between technology } \\
\text { buyers, suppliers, and completion of the } \\
\text { research collaboration between them }\end{array}$ & $\begin{array}{l}\text { Knowledge } \\
\text { Social }\end{array}$ & Conceptual & $\begin{array}{l}\text { Static/ } \\
\text { Certainty/ } \\
\text { Network }\end{array}$ \\
\hline $\begin{array}{l}\text { Glaeser and } \\
\text { Gottlieb [23] }\end{array}$ & 2009 & $\begin{array}{l}\text { "People cluster in cities to be close to } \\
\text { something. At their heart, agglomeration } \\
\text { economies are simply reductions in } \\
\text { transport costs for goods, people, and ideas" }\end{array}$ & Economic & $\begin{array}{l}\text { Qualitative/ } \\
\text { Conceptual }\end{array}$ & $\begin{array}{l}\text { Static/ } \\
\text { Certainty }\end{array}$ \\
\hline Wolman [24] & 2010 & "Firms in a region producing similar or & Economic & Qualitative/ & Static/ \\
\hline
\end{tabular}




\begin{tabular}{|c|c|c|c|c|c|}
\hline & & $\begin{array}{l}\text { related products, utilizing similar processes } \\
\text { or engaging in similar functions } \\
\text { (headquarters; R\&D), the regional suppliers } \\
\text { and customers of these firms, specialized } \\
\text { labor skills (occupations) possessed by } \\
\text { workers in the region employed by these } \\
\text { firms, public and public-private programs } \\
\text { that provide services to cluster around } \\
\text { members (e.g., customized training by } \\
\text { community colleges), and institutions (e.g., } \\
\text { universities, community colleges, industry } \\
\text { and trade associations, public and private } \\
\text { sector organizations) whose presence or } \\
\text { interaction, to the extent it exists (i.e., the } \\
\text { extent of interaction is an empirical } \\
\text { question), results in cost-savings to firms } \\
\text { and/or knowledge spillovers that produce } \\
\text { cost savings and/or product or process } \\
\text { innovations" }\end{array}$ & Social & Conceptual & $\begin{array}{l}\text { Certainty/ } \\
\text { Network }\end{array}$ \\
\hline UNIDO [25] & 2010 & $\begin{array}{l}\text { "Clusters as agglomerations of } \\
\text { interconnected companies and associated } \\
\text { institutions. Firms in a cluster produce } \\
\text { similar or related goods or services and are } \\
\text { supported by a range of dedicated } \\
\text { institutions located in spatial proximity, } \\
\text { such as business associations or training and } \\
\text { business development service (BDS) } \\
\text { providers. Networks can be established } \\
\text { between firms within clusters but also exist } \\
\text { outside clusters and can be horizontal and } \\
\text { vertical. Horizontal networks are built } \\
\text { between firms that target the same market. } \\
\text { Vertical networks are alliances between } \\
\text { firms belonging to different stages of the } \\
\text { same value chain" }\end{array}$ & $\begin{array}{l}\text { Economic } \\
\text { Social }\end{array}$ & Conceptual & $\begin{array}{l}\text { Static/ } \\
\text { Certainty/ } \\
\text { Network }\end{array}$ \\
\hline Del-Angizan [4] & 2011 & $\begin{array}{l}\text { Technology Clusters combine from } \\
\text { universities, technology parks, research } \\
\text { centers, and companies with superior } \\
\text { technology, human resources, and physical } \\
\text { infrastructure and institutional and human } \\
\text { capital that in a certain geographic area with } \\
\text { centralized management and specific legal } \\
\text { structure connection with a consumer } \\
\text { market to produce knowledge base goods } \\
\text { and services }\end{array}$ & $\begin{array}{l}\text { Knowledge } \\
\text { Social }\end{array}$ & Conceptual & $\begin{array}{l}\text { Static/ } \\
\text { Certainty }\end{array}$ \\
\hline Sheffi [26] & 2012 & $\begin{array}{l}\text { "A number of strengths linked to logistics } \\
\text { clusters. Moreover, logistics clusters } \\
\text { provide opportunities to train and develop a } \\
\text { skilled workforce internally. Furthermore, } \\
\text { logistics services serve diverse industries } \\
\text { and as a result, are more resilient to the } \\
\text { recession shocks" }\end{array}$ & $\begin{array}{l}\text { Economic } \\
\text { Social }\end{array}$ & Conceptual & $\begin{array}{l}\text { Static/ } \\
\text { Certainty/ } \\
\text { Network }\end{array}$ \\
\hline
\end{tabular}




\begin{tabular}{|l|c|l|l|l|l|}
\hline $\begin{array}{l}\text { Delgado, Porter } \\
\text { and Stern [27] }\end{array}$ & 2016 & $\begin{array}{l}\text { "Clusters are geographic concentrations of } \\
\text { industries related by knowledge, skills, } \\
\text { inputs, demand, and/or other linkages" }\end{array}$ & $\begin{array}{l}\text { Economic } \\
\text { Social }\end{array}$ & $\begin{array}{l}\text { Qualitative/ } \\
\text { Conceptual }\end{array}$ & $\begin{array}{l}\text { Static/ } \\
\text { Certainty/ } \\
\text { Network }\end{array}$ \\
\hline $\begin{array}{l}\text { Dezfoulian et al. } \\
\text { [5] }\end{array}$ & 2017 & $\begin{array}{l}\text { "Knowledge transfer in intra-organizational } \\
\text { and inter-organizational levels can be } \\
\text { carried out. The inter-organizational } \\
\text { knowledge transfer can be done horizontally } \\
\text { and vertically" }\end{array}$ & $\begin{array}{l}\text { Knowledge } \\
\text { Social }\end{array}$ & $\begin{array}{l}\text { Mathematical } \\
\text { mono- } \\
\text { objective } \\
\text { with a } \\
\text { variable of 4 } \\
\text { indices }\end{array}$ & $\begin{array}{l}\text { Static/ } \\
\text { Certainty/ } \\
\text { Network }\end{array}$ \\
\hline Lu et al. [28] & 2018 & $\begin{array}{l}\text { The cluster is a human nature that being to } \\
\text { be clustered in a certain region for business. } \\
\text { The relation of the clusters with together } \\
\text { will be constructed by firms/members inside } \\
\text { some clusters }\end{array}$ & $\begin{array}{l}\text { Economic } \\
\text { Social } \\
\text { Environment }\end{array}$ & $\begin{array}{l}\text { Conceptual/ } \\
\text { Review }\end{array}$ & $\begin{array}{l}\text { Static/ } \\
\text { Certainty/ } \\
\text { Network }\end{array}$ \\
\hline $\begin{array}{l}\text { Sarafrazi et al. } \\
\text { [29] }\end{array}$ & 2019 & $\begin{array}{l}\text { The clusters are a set of similar firms and } \\
\text { various entities that agglomerated in a } \\
\text { geographical zone and connected by co- } \\
\text { operation linkages within networks under } \\
\text { sustainable economic conditions }\end{array}$ & $\begin{array}{l}\text { Economic } \\
\text { Social } \\
\text { Environment }\end{array}$ & $\begin{array}{l}\text { Mathematical } \\
\text { Multi- } \\
\text { objective } \\
\text { With a } \\
\text { variable of 5 } \\
\text { indices }\end{array}$ & $\begin{array}{l}\text { Dynamic } \\
\text { Certainty/ } \\
\text { Network }\end{array}$ \\
\hline This study & 2021 & $\begin{array}{l}\text { The clusters have located in dynamic } \\
\text { and uncertainty conditions with many } \\
\text { changes in a new era }\end{array}$ & $\begin{array}{l}\text { Economic } \\
\text { Social } \\
\text { Environment }\end{array}$ & $\begin{array}{l}\text { Mathematical } \\
\text { multi- } \\
\text { objective } \\
\text { with a } \\
\text { variable of 5 } \\
\text { indices/ } \\
\text { Sensitivity } \\
\text { analysis for } \\
\text { demand/ } \\
\text { Firms } \\
\text { random select }\end{array}$ & $\begin{array}{l}\text { Dynamic } \\
\text { Uncertainty } \\
\text { / Efficiency } \\
\text { methods/ } \\
\text { New } \\
\text { proposed } \\
\text { method for } \\
\text { network } \\
\text { composition }\end{array}$ \\
\hline
\end{tabular}

Table 4. Uncertain production capacity and demand of industrial cluster firms.

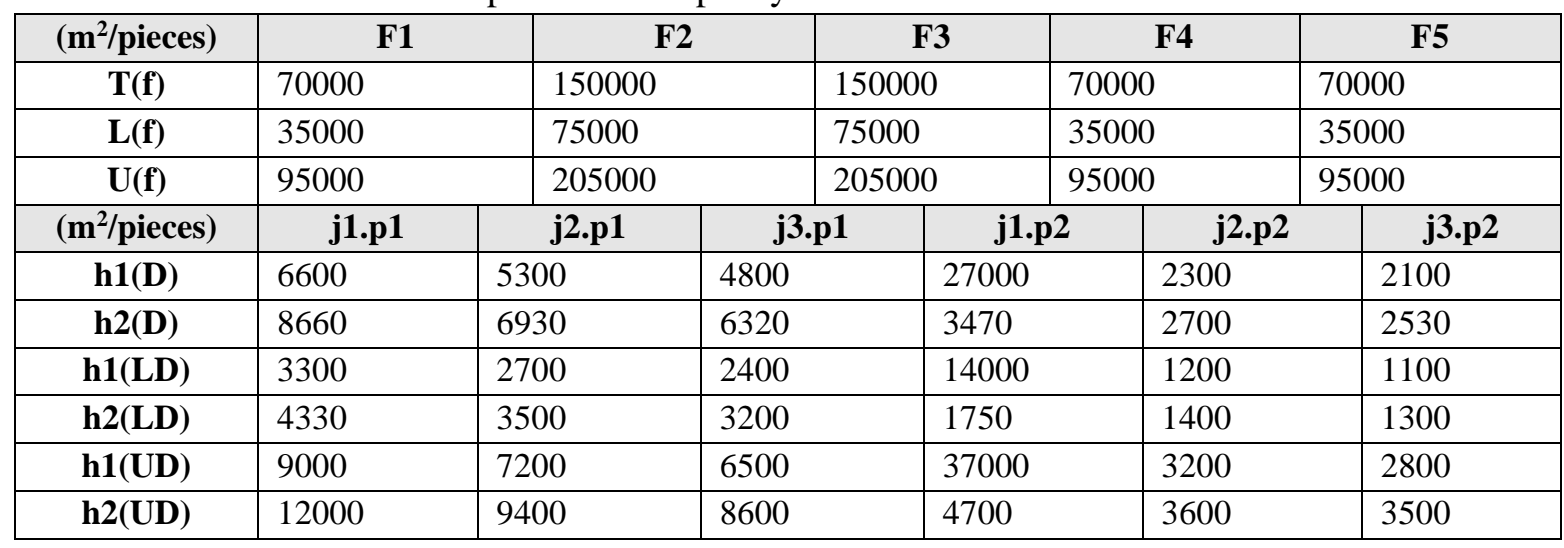

Table 5. Optimal solutions from the uncertain model for the industrial cluster.

\begin{tabular}{|c|c|c|c|c|c|c|c|c|c|c|c|c|}
\hline $\mathbf{P}$ & \multicolumn{3}{|c|}{ W1 } & \multicolumn{3}{|c|}{ W2 } & \multicolumn{3}{|c|}{ W3 } & \multicolumn{3}{|c|}{ W4 } \\
\hline 1 & \multicolumn{3}{|c|}{0.1} & \multicolumn{3}{|c|}{0.05} & \multicolumn{3}{|c|}{0.8} & \multicolumn{3}{|c|}{0.05} \\
\hline H1 & \multicolumn{6}{|c|}{$\mathrm{C} 1$} & \multicolumn{6}{|c|}{$\mathrm{C} 2$} \\
\hline $\mathrm{P}$ & \multicolumn{3}{|c|}{ P1 } & \multicolumn{3}{|c|}{ P2 } & \multicolumn{3}{|c|}{ P1 } & \multicolumn{3}{|c|}{ P2 } \\
\hline $\mathrm{J}$ & $\mathrm{J} 1$ & $\mathrm{~J} 2$ & $\mathrm{~J} 3$ & $\mathrm{~J} 1$ & $\mathrm{~J} 2$ & $\mathrm{~J} 3$ & $\mathrm{~J} 1$ & $\mathrm{~J} 2$ & $\mathrm{~J} 3$ & $\mathrm{~J} 1$ & $\mathrm{~J} 2$ & $\mathrm{~J} 3$ \\
\hline
\end{tabular}




\begin{tabular}{|c|c|c|c|c|c|c|c|c|c|c|c|c|}
\hline F1 & & & & 1 & & & & & & & & \\
\hline $\mathrm{F} 2$ & 1 & & & 1 & 1 & 1 & & & & 1 & & \\
\hline F3 & & & 1 & & & 1 & & & & & & \\
\hline F4 & & 1 & & & 1 & & & & & & & \\
\hline F5 & & & & & 1 & & & & & & 1 & \\
\hline $\mathrm{H} 2$ & \multicolumn{6}{|c|}{$\mathrm{C} 1$} & \multicolumn{6}{|c|}{$\mathrm{C} 2$} \\
\hline $\mathrm{P}$ & \multicolumn{3}{|c|}{ P1 } & \multicolumn{3}{|c|}{ P2 } & \multicolumn{3}{|c|}{ P1 } & \multicolumn{3}{|c|}{ P2 } \\
\hline $\mathrm{J}$ & $\mathrm{J} 1$ & $\mathrm{~J} 2$ & $\mathrm{~J} 3$ & $\mathrm{~J} 1$ & $\mathrm{~J} 2$ & J3 & J1 & $\mathrm{J} 2$ & J3 & J1 & $\mathrm{J} 2$ & $\mathrm{~J} 3$ \\
\hline F1 & & & & 1 & & & 1 & & & & & \\
\hline $\mathrm{F} 2$ & & & & & & & & & & 1 & & \\
\hline F3 & & & 1 & & & & & & & & & 1 \\
\hline $\mathrm{F} 4$ & & 1 & & & & & & & & & 1 & \\
\hline F5 & & & & & & & & & & 1 & 1 & 1 \\
\hline H1 & \multicolumn{6}{|c|}{$\mathrm{C} 1$} & \multicolumn{6}{|c|}{$\mathrm{C} 2$} \\
\hline $\mathrm{P}$ & \multicolumn{3}{|c|}{ P1 } & \multicolumn{3}{|c|}{$\mathrm{P} 2$} & \multicolumn{3}{|c|}{ P1 } & \multicolumn{3}{|c|}{ P2 } \\
\hline $\mathrm{K}$ & K1 & K2 & K3 & K1 & $\mathrm{K} 2$ & K3 & K1 & $\mathrm{K} 2$ & K3 & K1 & K2 & $\mathrm{K} 3$ \\
\hline F1 & 1 & 1 & 1 & & & & 1 & 1 & 1 & & & \\
\hline $\mathrm{F} 2$ & 1 & 1 & 1 & 1 & 1 & 1 & 1 & 1 & 1 & & & \\
\hline F3 & 1 & 1 & 1 & & & & 1 & 1 & 1 & & & \\
\hline $\mathrm{F} 4$ & 1 & 1 & 1 & & & & 1 & 1 & 1 & & & \\
\hline F5 & 1 & 1 & 1 & & & & 1 & 1 & 1 & & & \\
\hline $\mathrm{H} 2$ & \multicolumn{6}{|c|}{$\mathrm{C} 1$} & \multicolumn{6}{|c|}{$\mathrm{C} 2$} \\
\hline $\mathrm{P}$ & \multicolumn{3}{|c|}{ P1 } & \multicolumn{3}{|c|}{ P2 } & \multicolumn{3}{|c|}{ P1 } & \multicolumn{3}{|c|}{ P2 } \\
\hline $\mathrm{K}$ & K1 & K2 & K3 & K1 & K2 & K3 & K1 & $\mathrm{K} 2$ & K3 & K1 & K2 & $\mathrm{K} 3$ \\
\hline F1 & 1 & 1 & 1 & & & & 1 & 1 & 1 & & & \\
\hline $\mathrm{F} 2$ & 1 & 1 & 1 & & & & 1 & 1 & 1 & & & \\
\hline F3 & 1 & 1 & 1 & & & & 1 & 1 & 1 & & & \\
\hline $\mathrm{F} 4$ & 1 & 1 & 1 & & & & 1 & 1 & 1 & & & \\
\hline F5 & 1 & 1 & 1 & & & & 1 & 1 & 1 & 1 & 1 & 1 \\
\hline Lp & \multicolumn{3}{|c|}{$\mathrm{Z} 1 *($ K.USD $)$} & \multicolumn{3}{|c|}{$\mathrm{Z} 2 *$ (Person) } & \multicolumn{3}{|c|}{ Z3*(K.USD) } & \multicolumn{3}{|c|}{ Z4*(Score) } \\
\hline 14.78 & \multicolumn{3}{|c|}{39621.337} & \multicolumn{3}{|c|}{11.880} & \multicolumn{3}{|c|}{13814.20} & \multicolumn{3}{|c|}{2389.760} \\
\hline
\end{tabular}

Table 6. Efficiency measures for clustering of firms in the industrial cluster under uncertainty.

\begin{tabular}{|l|l|l|l|}
\hline Fuzzy:C1H1,C2H1/jpf & Raw (No.) & Column(No.) & Result \\
\hline The Neighbor Clustering Efficiency (NCE) & 4 & 6 & $36 \%$ \\
\hline The Ones Clustering Efficiency (OCE) & $3 / 5$ & $3 / 8$ & $37 \%$ \\
\hline C1H2,C2H2/jpf & Raw & Column & Result \\
\hline The Neighbor Clustering Efficiency (NCE) & 4 & 2 & $50 \%$ \\
\hline The Ones Clustering Efficiency (OCE) & 1 & 1 & $0 \%$ \\
\hline C1H1,C2H1/kpf & Raw & Column & Result \\
\hline The Neighbor Clustering Efficiency (NCE) & 48 & 48 & $0 \%$ \\
\hline The Ones Clustering Efficiency (OCE) & $5 / 2$ & $6 / 2$ & $17 \%$ \\
\hline C1H2,C2H2/kpf & Raw & Column & Result \\
\hline The Neighbor Clustering Efficiency (NCE) & 46 & 48 & $4 \%$ \\
\hline The Ones Clustering Efficiency (OCE) & $5 / 2$ & $6 / 2$ & $17 \%$ \\
\hline
\end{tabular}

Table 7. Efficiency of firms in industrial cluster networks under uncertainty.

\begin{tabular}{|r|c|c|c|r|c|c|c|}
\hline$j / \mathrm{H} 1$ & Frequency & $E_{f}$ & $E_{c}$ & $\mathrm{k} / \mathrm{H} 1$ & Frequency & $E_{f}$ & $E_{c}$ \\
\hline $\mathrm{F} 1$ & 1 & 0.42 & & $\mathrm{~F} 1$ & 6 & 0.91 & \\
\hline $\mathrm{F} 2$ & 5 & 1 & & $\mathrm{~F} 2$ & 9 & 1 & \\
\hline
\end{tabular}




\begin{tabular}{|c|c|c|c|c|c|c|c|}
\hline F3 & 2 & 0.83 & & F3 & 6 & 0.91 & \\
\hline F4 & 2 & 0.83 & & F4 & 6 & 0.91 & \\
\hline \multirow[t]{2}{*}{ F5 } & 2 & 0.83 & & F5 & 6 & 0.91 & \\
\hline & 2.4 & 3.91 & 0.78 & & 6.6 & 4.64 & 0.93 \\
\hline$j / \mathrm{H} 2$ & Frequency & $E_{f}$ & $E_{c}$ & $\mathrm{k} / \mathrm{H} 2$ & Frequency & $E_{f}$ & $E_{c}$ \\
\hline F1 & 2 & 1 & & $\mathrm{~F} 1$ & 6 & 0.91 & \\
\hline $\mathrm{F} 2$ & 1 & 0.5 & & F2 & 6 & 0.91 & \\
\hline F3 & 2 & 1 & & F3 & 6 & 0.91 & \\
\hline F4 & 2 & 1 & & F4 & 6 & 0.91 & \\
\hline \multirow[t]{2}{*}{ F5 } & 3 & 1 & & F5 & 9 & 1 & \\
\hline & 2 & 4.5 & 0.9 & & 6.6 & 4.64 & 0.93 \\
\hline
\end{tabular}

Table 8. Comparative of deterministic and uncertain models with optimal solutions of clusters

\begin{tabular}{|c|c|c|c|c|c|c|c|c|c|}
\hline $\mathrm{T}_{(f)}$ & W1 & W2 & W3 & W4 & $\mathrm{Z1}$ & $\mathrm{Z2}$ & $\mathrm{Z3}$ & $\mathrm{Z4}$ & $\operatorname{Min}(Z(L p))$ \\
\hline Deterministic & 0.1 & 0.05 & 0.8 & 0.05 & 34155.710 & 11.580 & 13814.200 & 2285.380 & 0.025 \\
\hline Fuzzy & 0.1 & 0.05 & 0.8 & 0.05 & 39621.337 & 11.880 & 13814.200 & 2389.760 & 14.787 \\
\hline \multirow{2}{*}{\multicolumn{5}{|c|}{$\begin{array}{l}\text { Improvement rate of optimal solutions for } \\
\text { firms capacity upper bound }\end{array}$}} & 5465.627 & 0.300 & 0.000 & 104.380 & - \\
\hline & & & & & $16.00 \%$ & $2.59 \%$ & $0.00 \%$ & $4.57 \%$ & - \\
\hline
\end{tabular}

Table 9. Model sensitivity analysis with optimal solutions of clusters.

\begin{tabular}{|c|c|c|c|c|c|c|c|c|c|}
\hline $\mathrm{T}_{(f)}$ & $\mathrm{W} 1$ & $\mathrm{~W} 2$ & $\mathrm{~W} 3$ & $\mathrm{~W} 4$ & $\mathrm{Z} 1$ & $\mathrm{Z} 2$ & $\mathrm{Z} 3$ & $\mathrm{Z} 4$ & $\mathrm{Min}(\mathrm{Z}(\mathrm{Lp}))$ \\
\hline Fuzzy & 0.1 & 0.05 & 0.8 & 0.05 & 39621.337 & 11.880 & 13814.200 & 2389.760 & 14.787 \\
\hline $\begin{array}{c}\text { Fuzzy } \\
(\lambda=0.7)^{*}\end{array}$ & \multicolumn{2}{|c|}{0.6} & \multicolumn{2}{|c|}{1.45} & 53309.337 & 11.880 & 16212.210 & 2389.760 & 13.862 \\
\hline Improvement & \multicolumn{2}{|c|}{ DLB $^{*}$} & \multicolumn{2}{|c|}{ DUB $^{*}$} & $34.55 \%$ & $0 \%$ & $-17.36 \%$ & $0 \%$ & $6.26 \%$ \\
\hline
\end{tabular}

* DLB: Demand lower bound; DUB: Demand upper bound; Parameter setting of fuzzy membership ( $\lambda$ ): 0.6-0.7

Table 10. New approach of the cluster model in the old and new proposed combinations of the network.

\begin{tabular}{|c|l|c|c|c|c|c|c|c|c|c|c|}
\hline $\begin{array}{c}\text { Network } \\
\text { Size }\end{array}$ & \multicolumn{1}{|c|}{$\begin{array}{c}\text { Model } \\
\text { status }\end{array}$} & W1 & W2 & W3 & W4 & Z1 & Z2 & \multicolumn{2}{|l|}{ Z3 } & $\begin{array}{c}\text { Min } \\
(\mathrm{Z}(\mathrm{Lp}))\end{array}$ \\
\hline $8 \mathrm{~F}_{\text {Old }}$ & Deterministic & 0.1 & 0.05 & 0.8 & 0.05 & 96826.37 & 12.66 & 19502.43 & 2367.71 & 11.438 \\
\hline \multicolumn{8}{|c|}{} \\
\hline $5 \mathrm{~F}_{\text {Old }}$ & Deterministic & 0.1 & 0.05 & 0.8 & 0.05 & 34155.710 & 11.580 & 13814.200 & 2285.380 & 0.0250 \\
\hline $5 \mathrm{~F}_{\text {New }}{ }^{*}$ & $\begin{array}{l}\text { Deterministic } \\
\text { Weighted }\end{array}$ & 0.1 & 0.05 & 0.8 & 0.05 & 43700.972 & 6.840 & 16435.750 & 1952.190 & 4468.04 \\
\hline $5 \mathrm{~F}_{\text {New }}$ & $\begin{array}{l}\text { Deterministic } \\
\text { LP metric }\end{array}$ & 0.1 & 0.05 & 0.8 & 0.05 & 74021.782 & 10.740 & 11896.904 & 2352.280 & 0.0226 \\
\hline $5 \mathrm{~F}_{\text {New }}$ & $\begin{array}{l}\text { Fuzzy } \\
\text { LP metric }\end{array}$ & 0.1 & 0.05 & 0.8 & 0.05 & 95430.382 & 10.020 & 9862.318 & 2433.150 & 0.797 \\
\hline
\end{tabular}

${ }^{*} 5 \mathrm{~F}_{\mathrm{New}}$ is a new composition of networks consisting of 5 and 8 firms $[(\mathrm{F} 1-5)+(\mathrm{F} 1-8)=(\mathrm{F} 1, \mathrm{~F} 2, \mathrm{~F} 6, \mathrm{~F} 7, \mathrm{~F} 8)]$

Table 11. Comparison of changes and growth of model objectives with the number of optimal members of the research and experimental co-operation networks.

\begin{tabular}{|c|c|c|c|c|c|c|}
\hline Method & F(Up, Low) & Size & Z1(Max) & Z2(Max) & Z3(Min) & Z4(Max) \\
\hline Experience & {$[8,12]$} & 1.50 & 1.31 & 1.41 & 1.87 & 1.66 \\
\hline 글 Research & {$[5,8]$} & 1.60 & $2.44 \Uparrow$ & 1.07 & 1.41 亿 & 0.99 亿 \\
\hline Improvement & {$[37.5,33.33 \%]$} & $6.67 \%$ & $86.26 \%$ & $-24.11 \%$ & $24.60 \%$ & $40.36 \%$ \\
\hline
\end{tabular}




\section{Biographies}

Abbas Sarafrazi is currently the Ph.D. under the supervision of Prof. Reza Tavakkoli-Moghaddam in Department of Industrial Engineering at Payame Noor University, Iran. He obtained his B.Sc. degree from Islamic Azad University - Arak Branch in 1994 and M.Sc. in Industrial Engineering from Mazandaran University of Science and Technology in Babol in 2001. He trained by UNIDO, ISIPO, and ITC then worked professional in Industrial clusters and Economic development projects since 2006 under cluster development agent and technical adviser about 25 projects and studies in ISIPO. He received an award for the best cluster development project from the Islamic Azad University Science and Research Branch in Arak in 2009. His research interests include clustering and data mining and data analysis, industrial clusters, sustainability; uncertainty analysis, and networks. He has published a few papers in cluster field.

Reza Tavakkoli-Moghaddam is a distinguished Professor of Industrial Engineering at College of Engineering, University of Tehran in Iran. He obtained his Ph.D. in Industrial Engineering from Swinburne University of Technology in Melbourne (1998), his M.Sc. in Industrial Engineering from the University of Melbourne in Melbourne (1994) and his B.Sc. in Industrial Engineering from the Iran University of Science and Technology in Tehran (1989). He serves as Editorial Board of five reputable academic journals. He is the recipient of the 2009 and 2011 Distinguished Researcher Awards and the 2010 and 2014 Distinguished Applied Research Award at University of Tehran, Iran. He has been selected as National Iranian Distinguished Researcher for 2008 and 2010. He has obtained the outstanding rank as the top $1 \%$ scientist and researcher in the world elite group since 2014. He has published 4 books, 23 book chapters, and more than 1000 journal and conference papers.

Mahdi Bashiri has been a Professor of Industrial Engineering at Shahed University and also has been an assistant professor in Business Analytics in School of Strategy \& Leadership, Coventry University in UK. He obtained his B.Sc. degree in Industrial Engineering from Iran University of Science and Technology, M.Sc. and Ph.D. degrees from Tarbiat Modares University. He is a recipient of the 2013 young national top scientist award from the Academy of Sciences of the Islamic Republic of Iran. He has served as the Editor-in-Chief of Journal of Quality Engineering and Production Optimization and the Editorial Board member of three reputable academic journals. His research interests are facilities design, Heuristic algorithms, and multi-response optimization. He has published about 6 books and more than 300 papers in reputable academic journals and conferences.

Gholamreza Esmaeilian is currently an Assistant Professor at Department of Industrial Engineering in Payame Noor University in Iran. He obtained his Ph.D. in Industrial Engineering at University of Putra Malaysia (UPM) in 2010. He also holds both B.Sc. and M.Sc. degrees in Industrial Engineering. His areas of interests are optimization, operations management, parallel assembly lines, and maintenance. He has written numerous articles in credible journals in these fields and has participated in many conferences. 